\title{
Climate, Environment, and Disturbance History Govern Resilience of Western North American Forests
}

Paul F. Hessburg ${ }^{1,2 *}$, Carol L. Miller ${ }^{3}$, Sean A. Parks ${ }^{3}$, Nicholas A. Povak ${ }^{1}$, Alan H. Taylor ${ }^{4}$, Philip E. Higuera ${ }^{5}$, Susan J. Prichard ${ }^{2}$, Malcolm P. North ${ }^{6}$, Brandon M. Collins ${ }^{7}$, Matthew D. Hurteau ${ }^{8}$, Andrew J. Larson ${ }^{9}$, Craig D. Allen ${ }^{10}$, Scott L. Stephens ${ }^{11}$,

OPEN ACCESS

Edited by:

Jeanne C. Chambers,

United States Department of Agriculture (USDA), United States

Reviewed by:

David W. Huffman,

Northern Arizona University,

United States

Christopher Carcaillet,

Ecole Pratique des Hautes Etudes

(EPHE), PSL Research

University, France

*Correspondence:

Paul F. Hessburg

paul.hessburg@usda.gov

Specialty section:

This article was submitted to Biogeography and Macroecology,

a section of the journal

Frontiers in Ecology and Evolution

Received: 23 December 2018

Accepted: 11 June 2019

Published: 10 July 2019

Citation:

Hessburg PF, Miller CL, Parks SA, Povak NA, Taylor AH, Higuera PE, Prichard SJ, North MP, Collins BM,

Hurteau MD, Larson AJ, Allen $C D$,

Stephens SL, Rivera-Huerta H, Stevens-Rumann CS, Daniels $L D$

Gedalof Z, Gray RW, Kane VR,

Churchill DJ, Hagmann RK, Spies TA,

Cansler CA, Belote RT, Veblen TT,

Battaglia MA, Hoffman C, Skinner CN,

Safford HD and Salter RB (2019)

Climate, Environment, and

Disturbance History Govern Resilience of Western North American Forests.

Front. Ecol. Evol. 7:239.

doi: 10.3389/fevo.2019.00239
Hiram Rivera-Huerta ${ }^{12}$, Camille S. Stevens-Rumann ${ }^{13}$, Lori D. Daniels ${ }^{14}$, Ze'ev Gedalof ${ }^{15}$, Robert W. Gray ${ }^{16}$, Van R. Kane ${ }^{2}$, Derek J. Churchill ${ }^{17}$, R. Keala Hagmann ${ }^{2}$, Thomas A. Spies ${ }^{18}$, C. Alina Cansler ${ }^{19}$, R. Travis Belote ${ }^{20}$, Thomas T. Veblen ${ }^{21}$, Mike A. Battaglia ${ }^{22}$, Chad Hoffman ${ }^{23}$, Carl N. Skinner ${ }^{24}$, Hugh D. Safford $^{25}$ and R. Brion Salter ${ }^{1}$

\begin{abstract}
${ }^{1}$ Pacific Northwest Research Station, USDA-FS, Wenatchee, WA, United States, ${ }^{2}$ SEFS, College of the Environment, University of Washington, Seattle, WA, United States, ${ }^{3}$ Rocky Mountain Research Station, Aldo Leopold Wilderness Research Institute, Missoula, MT, United States, ${ }^{4}$ Department of Geography, and Earth and Environmental Systems Institute, Pennsylvania State University, University Park, PA, United States, ${ }^{5}$ Department of Ecosystem and Conservation Sciences, University of Montana, Missoula, MT, United States, ${ }^{6}$ Pacific Southwest Research Station, USDA-FS, Davis, CA, United States, ${ }^{7}$ Center for Fire Research and Outreach, University of California, Berkeley, Berkeley, CA, United States, ${ }^{8}$ Department of Biology, University of New Mexico, Albuquerque, NM, United States, ${ }^{9}$ Department of Forest Management, University of Montana, Missoula, MN, United States, ${ }^{10}$ New Mexico Landscapes Field Station, USDI-USGS, Los Alamos, NM, United States, " Department of Environmental Science, Policy, and Management, University of California, Berkeley, Berkeley, CA, United States, ${ }^{12}$ Marine Science Faculty, Universidad Autónoma de Baja California, Ensenada, Mexico, ${ }^{13}$ Colorado State University, Fort Collins, CO, United States, ${ }^{14}$ Department of Geography, University of British Columbia, Vancouver, BC, Canada, ${ }^{15}$ Department of Geography, University of Guelph, Guelph, ON, Canada, ${ }^{16}$ RW Gray Consulting Ltd, Chilliwack, BC, Canada, ${ }^{17}$ Washington Department of Natural Resources, Olympia, WA, United States, ${ }^{18}$ Pacific Northwest Research Station, USDA-FS, Corvallis, OR, United States, ${ }^{19}$ Fire Sciences Laboratory, Rocky Mountain Research Station, Missoula, MT, United States, ${ }^{20}$ Northern Rockies Regional Office, The Wilderness Society, Bozeman, MT, United States, ${ }^{21}$ Department of Geography, University of Colorado, Boulder, CO, United States, ${ }^{22}$ Rocky Mountain Research Station, USDA-FS, Fort Collins, CO, United States, ${ }^{23}$ Department of Forest and Rangeland Stewardship, Colorado State University, Fort Collins, CO, United States, ${ }^{24}$ Pacific Southwest Research Station, USDA-FS, Redding, CA, United States, ${ }^{25}$ USDA Forest Service, Pacific Southwest Region, Vallejo, CA, United States
\end{abstract}

Before the advent of intensive forest management and fire suppression, western North American forests exhibited a naturally occurring resistance and resilience to wildfires and other disturbances. Resilience, which encompasses resistance, reflects the amount of disruption an ecosystem can withstand before its structure or organization qualitatively shift to a different basin of attraction. In fire-maintained forests, resilience to disturbance events arose primarily from vegetation pattern-disturbance process interactions at several levels of organization. Using evidence from 15 ecoregions, spanning forests from Canada to Mexico, we review the properties of forests that reinforced qualities of resilience and resistance. We show examples of multi-level landscape resilience, of feedbacks within and among levels, and how conditions have changed under climatic and management influences. We highlight geographic similarities and important differences in the structure and organization of historical landscapes, their forest types, and in the conditions that have changed resilience and resistance to abrupt or large-scale 
disruptions. We discuss the role of the regional climate in episodically or abruptly reorganizing plant and animal biogeography and forest resilience and resistance to disturbances. We give clear examples of these changes and suggest that managing for resilient forests is a construct that strongly depends on scale and human social values. It involves human communities actively working with the ecosystems they depend on, and the processes that shape them, to adapt landscapes, species, and human communities to climate change while maintaining core ecosystem processes and services. Finally, it compels us to embrace management approaches that incorporate ongoing disturbances and anticipated effects of climatic changes, and to support dynamically shifting patchworks of forest and non-forest. Doing so could make these shifting forest conditions and wildfire regimes less disruptive to individuals and society.

Keywords: resistance, meta-stability, climatic forcing, persistence, sustainability, self-organization, adaptive management

\section{INTRODUCTION}

The concepts of resilience and resistance broadly apply to ecological systems; they reflect the allied capacities of systems to regain and retain their fundamental structure, organization, and processes when impacted by stresses or disturbances (Holling, 1973). Resilient ecosystems are hierarchically organized (possessing unique structure and processes at several levels of organization) and adaptive (adjusting to environmental, climatic, and disturbance conditions; Angeler and Allen, 2016, and references therein). Conditions at each level of organization can exist in alternate states, or "basins of attraction" (Figure 1). Multi-level patterns, which fluctuate over space and time, emerge from periodic disturbances or stresses. Disturbances occur at predictable frequencies, within probable event-size distributions, and over a range of intensities that are unique to each level of organization; their frequency, size, and intensity depend upon the climatic and biophysical conditions at each level.

While helpful, this construct can miss interactive properties of resilience and resistance that are germane to landscapes exposed to wildfires, climate change, and humans. For example, Walker et al. (2004) portrayed resistance as a core component of resilience, where resilience depends on basin width (latitude$\mathrm{L})$, depth (resistance-R), proximity to the lip (precariousness-Pr), wall steepness, and panarchy-the strength of other impinging top-down and/or bottom-up influences (Figure 1). In a resilient system, it's unnecessary that any former position in a basin is regained, so long as the system remains in the basin. If the system is also resistant, it resides deep in the basin. Over time, resilient systems can share highly similar characteristics, but no two are identical. Instead, resilient systems tend to resonate within a cloud of conditions that define the latitude, depth, and shape of the basin (Scheffer et al., 2001). As resistance declines, so too does resilience. Without reestablishing durable resistance, future stresses likely result in system shifts to other basins of attraction (Tepley et al., 2018).

As global and regional temperatures and moisture deficits rise-leading to longer fire seasons and more pronounced seasonal drought-wildfire burned area is increasing in many
Earth biomes, including those of western North America (Jolly et al., 2015; Abatzoglou and Williams, 2016). Highly altered fire frequency, severity, seasonality, and spatial extent can singly or collectively cause ecosystem change, particularly when coupled with climatic changes. Large patches $\left(>10^{3} \mathrm{ha}\right)$ of highseverity $[>75 \%$ of tree basal area [BA] or canopy cover [CC] killed] fires can catalyze changes in species distributions and community composition, because many plants are vulnerable during germination, establishment, and seedling life stages (Sprugel, 1991; Williams and Jackson, 2007). Combined with stresses imposed by human development and non-native species invasions, wildfires are testing the resilience and resistance of ecosystems worldwide (Holling, 1986; Davis et al., 2018; StevensRumann et al., 2018). As climate and fire regimes change, new understanding is needed of both the inherent resilience of these novel ecosystems and of the implications to human communities and the ecosystem services they rely on.

In following sections, we examine the properties of dry, moist, cold, and boreal forests of the Western United States (US), Mexico (MX), and British Columbia (BC), Canada that make them resilient and resistant to wildfires and other stressors. We focus on drier forest ecoregions where fire and other disturbance agents are especially active. Fire is less frequent in moist to wet coastal forests of western North America, although research shows that wildfire and suppression of wildfire can affect ecosystem resilience in drier portions of the moist Douglas-fir/western hemlock forest type (Tepley et al., 2013). Despite border-crossing ecoregions and type similarities, forests of the US, Canada and Mexico are treated separately due to their distinct fire and forest management histories. We discuss the role of the ecoregional climate in episodically or abruptly reorganizing plant and animal biogeography or disturbance regimes (i.e., the frequency, severity, seasonality, and extent of disturbances). Using evidence from 15 Bailey ecoregions (Bailey, 1998, Figure 2) with varying forest types, we show clear examples of multi-level, historical forest landscape resilience; of cross-connections between levels; and change in resilient and resistant conditions under climatic and anthropogenic forcing. For example, aboriginal burning throughout western North 


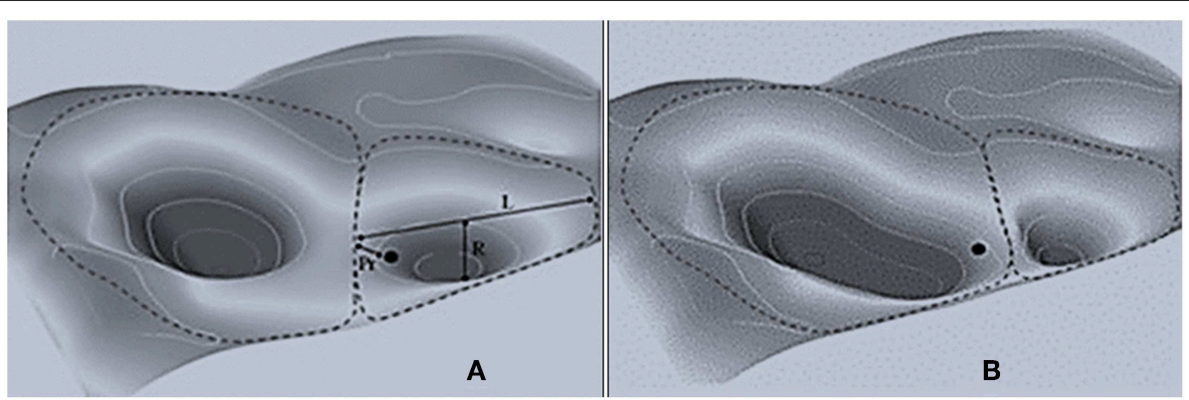

FIGURE 1 | Two landscapes (basins of attraction) and their constituent resilience attributes (from Walker et al., 2004 reprinted with permission). (A) A 3-D stability landscape showing two basins of attraction (dotted lines). In the smaller basin, the current position of the system (black dots) and three aspects of resilience, L, latitude (width of the basin), R, resistance (depth of the basin), and Pr, precariousness (proximity to the basin lip). (B) Changes in the broader landscape can result in contraction of the basin and expansion of an alternate basin. Without changing itself, the system has changed basins of attraction and is precariously positioned for additional changes.

America both buffered and amplified fire-climate interactions at patch to ecoregion levels (Taylor et al., 2016). Modern human populations can also increase an ecosystem's ignition frequencychanging its wildfire regime (Balch et al., 2017)_or human land uses can weaken or nullify climate influences on fire regimes (Syphard et al., 2017; Wahl et al., 2019).

We highlight geographic similarities and differences in the structure and organization of resilient landscapes, and in the conditions that alter resilience and resistance to abrupt or large-scale disruptions. We document similarities to reveal system-level properties that consistently emerge from broadly different physiographic domains, under the common influence of wildfires. Despite notable differences in regional geology, climate, and human interactions, we find fundamental properties guiding forest resilience and resistance across western North America. Multi-level pattern-process linkages exist between vegetation and disturbances, which co-adapt to changing environmental conditions and climate without altering their fundamental characteristics. Where these linkages are broken through abrupt changes in climatic forcing or by removing key disturbances from the landscape, vegetation dynamics can shift, and novel states or ecosystems can emerge, potentially compromising resilience to future disturbances.

\section{THE CLIMATE OF WESTERN NORTH AMERICA-PAST, PRESENT, AND FUTURE}

We begin our review by describing the influence of climate on fire regimes of western North American forests. Variability in regional climate strongly shapes forests and fire regimes, as well as any resilience or resistance they possess to stressors. Seasonal to annual temperature and precipitation are main drivers of forest productivity (Figure 3), which is often reflected in overstory and understory species composition, and overall forest structure (Stephenson, 1998). Productivity along with prior disturbance history determines the amount and characteristics of fuels, while seasonal variability in temperature and precipitation determine fuel moisture and availability to burn (Figures 3B,C).
Thus, ecoregions can be described by distinctive space they inhabit along this productivity gradient, which runs from coolwet to warm-dry climatic conditions (Figure 3D).

Among forest types of an ecoregion, wildfire regimes are typically climate-limited, where weather and atmospheric conditions are seldom sufficiently dry for combustion to occur, or fuel-limited, where frequent fires have consumed fuels or aridity limits abundance, or they are hybrid systems (Figure 3D, Agee, 1996; Krawchuk and Moritz, 2011). Fire regimes across this spectrum likewise vary, directly influencing the ways in which forests exhibit resilience and resistance to wildfires. At the moist end of the productivity gradient (Figures 3C,D), wildfire activity is directly climate-limited through occasional droughts that dry out naturally dense and typically moist vegetation (McKenzie and Littell, 2017). The wet forests of the coastal Pacific Northwest and western Cascade Mountains, cold subalpine, and some moist forests at moderate to high elevation or high latitude exemplify this scenario. Many summers, fire is limited by high fuel moisture or lack of ignitions; widespread burning is constrained to years with unusually severe drought. Under these more extreme conditions, high-severity fire effects may result in extensive tree mortality. Cold subalpine forests historically exhibited resilience to severe fires through tree species traits (e.g., cone serotiny, wind, bird, or mammal-dispersed seeds) and favorable climate that allowed for postfire regeneration; species composition and other properties returned to pre-fire conditions within decades to centuries (Baker, 2009). However, we note that even at the coldest and wettest end of this gradient there was variation in historical fire severity: fires burning under moderate fire weather generally exhibited more mixed-severity fire effects, including low- and moderate-severity patches $(<25 \%$, and $25-75 \%$ of tree BA or CC killed, respectively).

Fuel-limited ecosystems exist at the low end of the productivity gradient, where warm-dry climates contribute to area burned indirectly through their influence on woody fuel abundance and ignition frequency (Agee, 1996; Krawchuk and Moritz, 2011). While fuel moisture is often low and conducive to ignition, sparse understory vegetation and low tree density can limit surface fuels, fire spread, and flame lengths, making 


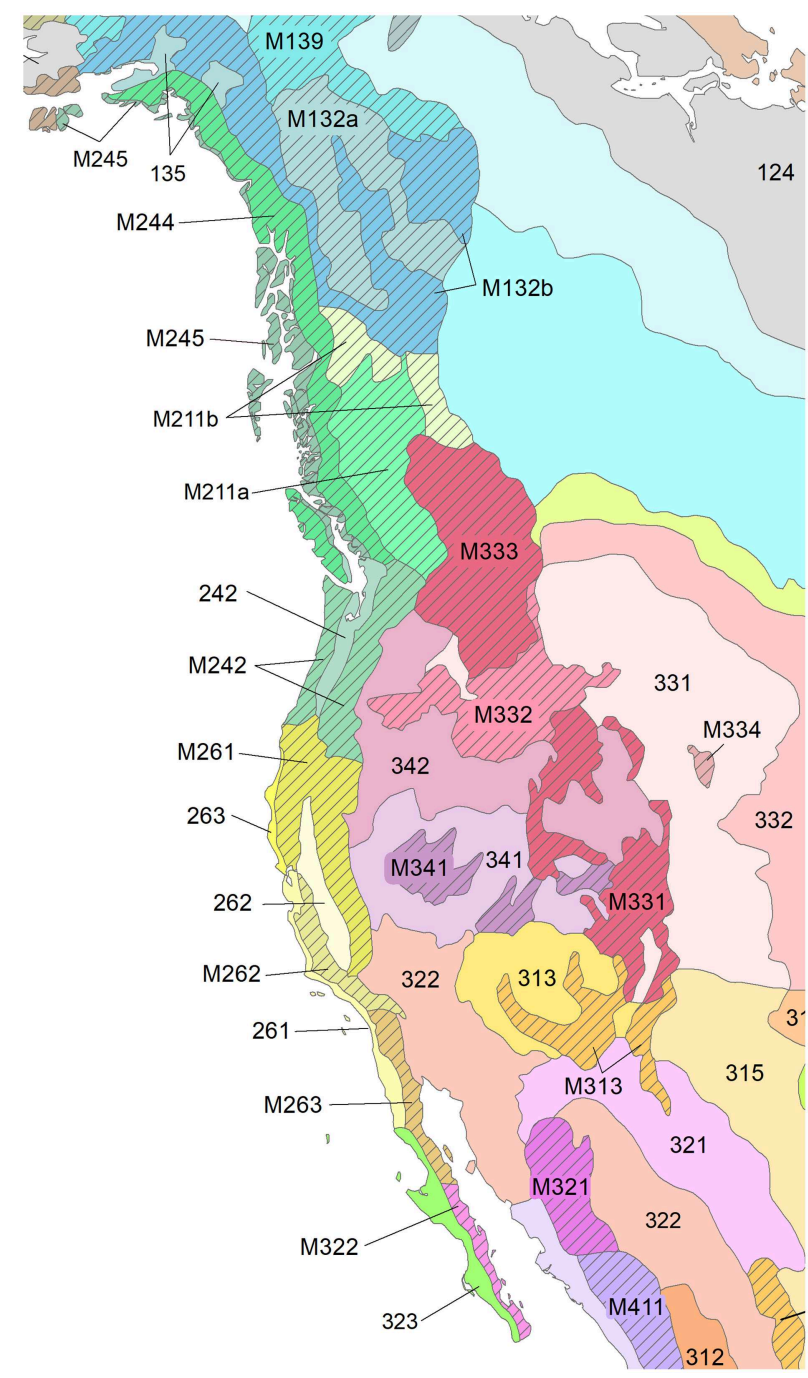

FIGURE 2 | Bailey provinces of western North America (Bailey, 1998). 135-Taiga-tundra, medium, M132a-Taiga-tundra, medium, M132b-Taiga-tundra, high, M139-Open woodland-tundra, M211a-Mixed forest-coniferous forest-tundra, medium, M211b-Mixed forest-coniferous forest-tundra, high, 242-Mixed forests, M242-Deciduous or mixed forest-coniferous forest-meadow, M244-Forest-meadow, high, M245-Forest-meadow, medium, 261-Dry steppe, 262-Mediterranean hard-leaved evergreen forests, open woodlands and shrub, 263-Redwood forests, M261-Mixed forest-coniferous forest-alpine meadow, M262-Mediterranean woodland or shrub-mixed or coniferous forest-steppe or meadow, M263-Shrub or

woodland-steppe-meadow, 313-Coniferous open woodland and semideserts, 315-Shortgrass steppes, M313-Steppe or semidesert-mixed forest-alpine meadow or steppe, 321-Semideserts, M321-Semidesert-shrub-open woodland-steppe or alpine meadow, M322-Desert or semidesert-open woodland or shrub-desert or steppe, 331-Dry steppes, 332-Steppes, M331-Steppe-open woodland-coniferous forest-alpine meadow, M332-Steppe-coniferous forest-tundra, M333-Forest-steppe-coniferous forest-meadow-tundra, M334 - Steppe-coniferous forest, 341-Semideserts and deserts, 342-Semideserts, M341-Semidesert-open woodland-coniferous forest-alpine meadow, M411-Open woodland-deciduous forest-coniferous forest-steppe or meadow. Reprinted with permission. it difficult to initiate and spread crownfire. Another indirect influence of climate on fire activity occurs when above-average moisture availability promotes production of grass and herb cover, which facilitates widespread burning in subsequent years (Swetnam and Betancourt, 1998). Fires in fuel-limited systems typically burn with low- to moderate-severity, and due to a combination of fire behavior, species traits, and frequent woody fuel consumption, tree mortality can be low to moderate. Dry pine and mixed-conifer forests in lower elevations and at lower latitudes exemplify this scenario. Historically, thickbarked tree species (e.g., ponderosa pine-Pinus ponderosa, Jeffrey pine-P. jeffreyi, Douglas-fir-Pseudotsuga menziesii, and western larch-Larix occidentalis), and certain fire-adapted understory vegetation (e.g., bunchgrasses-Festuca spp., Agropyron spp., Poa spp., Koelaria spp., pinegrasses-Calamagrostis spp., buckbrushCeanothus spp., sagebrush-Artemisia spp., and bitterbrushPurshia spp.) exhibited resistance to surface fires, surviving, or resprouting from roots or buried seeds in the weeks to years following fire.

Between this simplified dichotomy of climate- and fuellimited are so-called "hybrid" systems (McKenzie and Littell, 2017), and they include a variety of mixed-conifer forests. Fires in these forests often burn with moderate-severity (Agee, 1996; Schoennagel et al., 2004; Hessburg et al., 2007), resulting in mixed surface and crownfire behavior and effects. Although simplified, this tripartite grouping is useful for understanding past and contemporary fire regimes, and how twenty-first-century climate change might impact fire regimes and forest resilience.

Climate has a strong influence on annual area burned. Robust correlations between seasonal to annual climate metrics and area burned (Higuera et al., 2015; Littell et al., 2018) implicate climate as the main driver of area burned. Tree-ring, lakesediment, and paleoclimatic records from the more distant past highlight aspects of fire and forest resilience that provide important context for twenty-first-century change. For example, climate variability of the last millennium correlates well with area burned at interannual and centennial time scales. Years with large burned area are linked with warm-dry conditions (Schoennagel et al., 2005; Heyerdahl et al., 2008b; Williams et al., 2013), and area burned over decades to centuries broadly tracks variability in temperature and drought (Kitzberger et al., 2007; Marlon et al., 2012; Calder et al., 2015). In some cases, past periods of widespread burning associated with regional drought compromised forest resilience to wildfires, triggering shifts to non-forest, some of which persist today (Calder and Shuman, 2017). Documented shifts in the paleoclimatic record provide insights as to what we might expect under a warmerdrier climate.

Climate projections for western North America suggest that water deficits will increase over the twenty-first-century (Abatzoglou and Williams, 2016; McKenzie and Littell, 2017; Littell et al., 2018), with implications for future area burned and post-fire recovery of many forests (Davis et al., 2018, 2019). Expected outcomes vary across our tripartite grouping. For example, in cold and some moist forests, where fire has been 

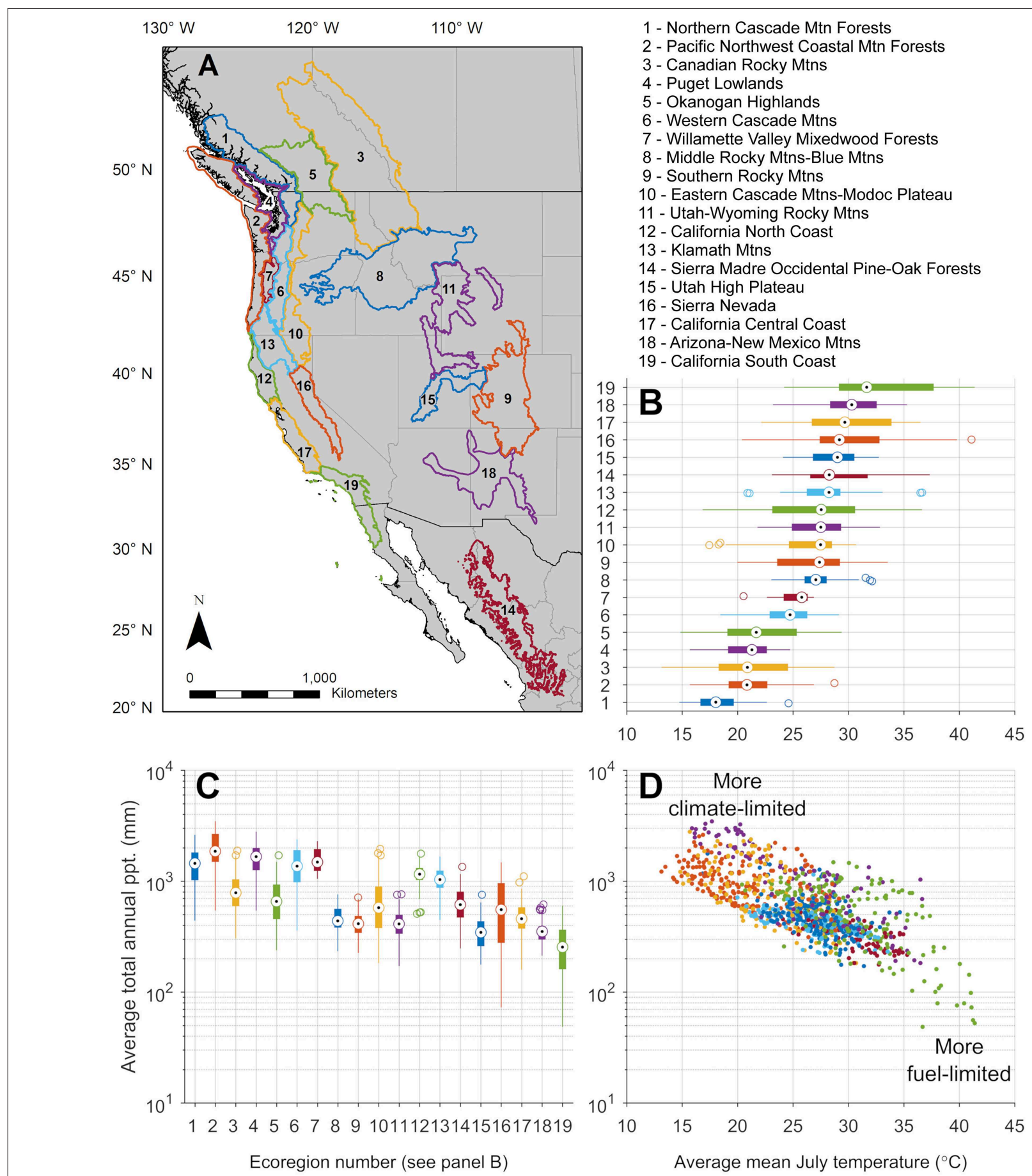

FIGURE 3 | Climatic ecoregions of western North America referenced in the text, in geographic (A) and climate space (B-D). Ecoregions are organized in (B) by increasing average mean July temperature, from bottom to top; the same ordering is used in (C) for average total annual precipitation, from left to right. Globally, these two climate variables are the most relevant for predicting fire presence/absence (Krawchuk et al., 2009). Values in (B,C) define climate space (D) occupied by each 0.5 degree latitude grid cell, in each ecoregion. Ecoregions are based on Bailey (1998) but subdivided in The Nature Conservancy Terrestrial Ecoregions (Olson and Dinerstein, 2002). Climate data are from the Climate Research Unit (New et al., 1999), represent $1961-1990$ average values, with a $0.5^{\circ}$ spatial resolution.

climate-limited, burned area will likely increase in the near term. Warmer-drier summers already facilitate greater burned area due to increased frequency and duration of seasonal droughts, which increases fuel availability to burn (Holden et al., 2018). Significant fuel accumulation and lower fuel moisture within a fire season will increase fire severity, which could reduce seed 
availability for post-fire regeneration. As landscapes burn more frequently, forests with previously climate-limited fire regimes will see a decrease in woody fuels as they are consumed by fire (cf. Littell et al., 2018), and postfire revegetation by forest tree species slows. At the same time, these forests could see increased grass and herbaceous fuels. Forest resilience to highseverity wildfires is thus expected to change where fire is currently climate-limited, with recovery to forest potentially taking longer than observed over the twentieth-century, or not occurring at all (Davis et al., 2018; Stevens-Rumann et al., 2018). In ecosystems where fire is fuel-limited, an increased water deficit will likely decrease productivity and future burned area (Krawchuk and Moritz, 2011; McKenzie and Littell, 2017; Littell et al., 2018). Dry forests at lower elevations and in lower latitudes may see their fire regimes become even more fuel-limited, and some may transition to non-forest with invasive or non-invasive annuals and highfrequency, high-severity fires. For those hybrid ecosystems that characteristically supported moderate-severity fire, and in forests where high tree densities reflect natural postfire cohorts (Schoennagel et al., 2004), increased moisture deficits could lead to increasing fire severity, especially where prior land use and fire suppression have contributed to fuel ladders and elevated surface fuels. These ecosystems are particularly vulnerable to wildfires, as species traits that historically conferred resistance to low- and moderate-severity fires neither provide resistance nor resilience to crownfires.

\section{RESILIENCE AND RESISTANCE IN WESTERN NORTH AMERICAN FORESTS}

\section{British Columbian Forests}

The westernmost province in Canada, British Columbia (BC), covers 94 million ha, including 60 million forested hectares. The province is physiographically diverse, spanning 10 degrees of

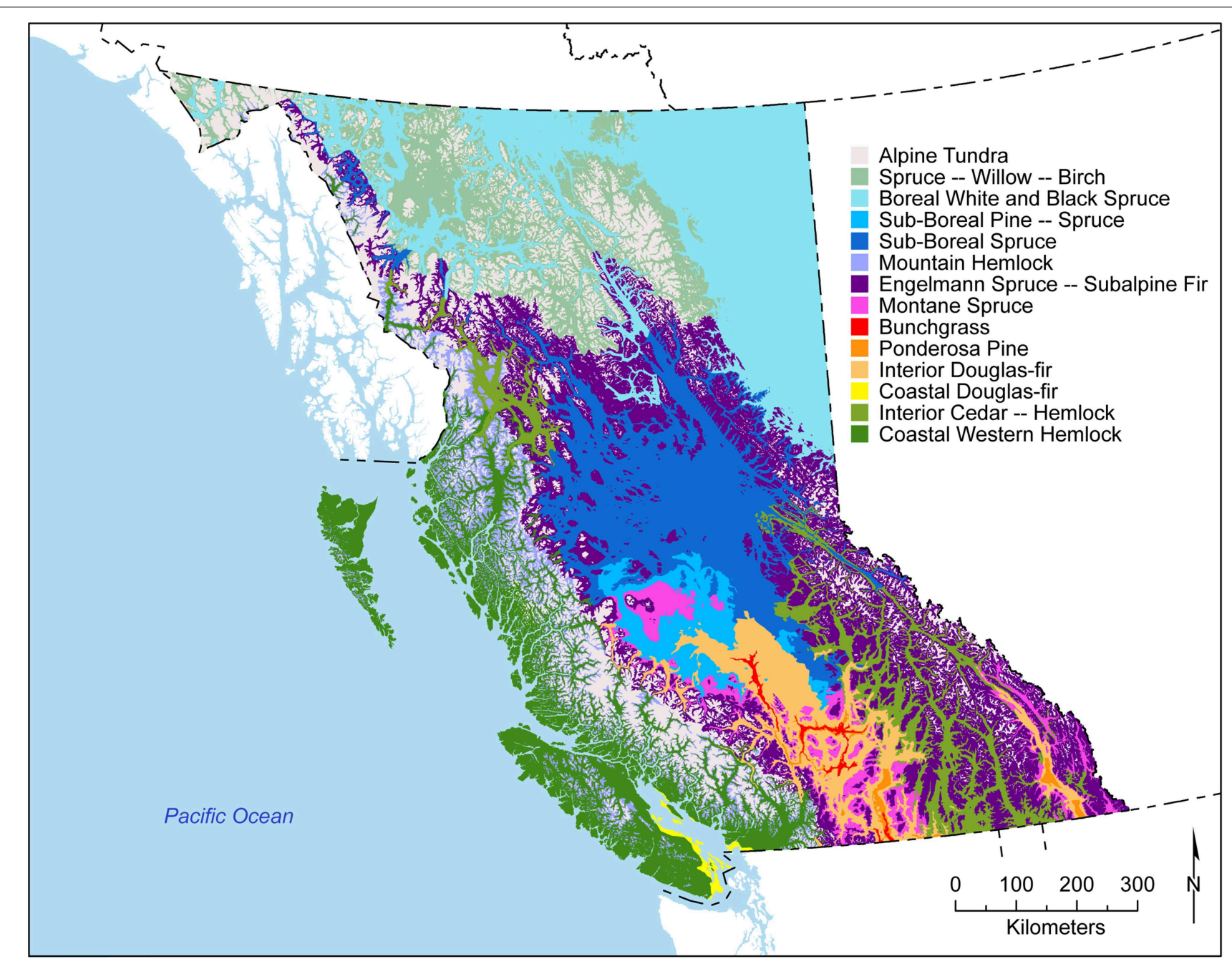

FIGURE 4 | Biogeoclimatic zones of British Columbia (Meidinger and Pojar, 1991). Alpine Tundra includes the Boreal Altai Fescue Alpine, Coastal Mountain-heather Alpine, and Interior Mountain-heather Alpine zones. Data source: British Columbia Ministry of Forest Lands and Natural Resource Operations; map by Raphaël Chavardès and Shuojie Li) 
latitude, and the Coast, Cascade, and Rocky Mountain ranges (Figures 2, 3, M333, M211a, M211b, M242, M245, M132a, $\mathrm{M} 132 \mathrm{~b}$ ). It encompasses 16 biogeoclimatic zones (Meidinger and Pojar, 1991, Figure 4) with diverse ecosystems including coastal temperate rainforests, grasslands, and cold subalpine forests, which reside along broad latitudinal and elevational gradients of temperature and precipitation.

East of the coastal forests and mountains (Figure 4), premanagement era disturbance regimes were complex and variable, with fire as a dominant agent (Boulanger et al., 2014). In plateau and mountain dry mixed-conifer forests (interior Douglas-fir often mixed with lodgepole pine ( $P$. contorta) and occasionally ponderosa pine and western larch in extreme southern BC), historical moderate-severity fire regimes included frequent surface fires at the lowest elevations, transitioning to infrequent crownfires at higher elevations (Marcoux et al., 2013, 2015; Chavardès and Daniels, 2016; Greene and Daniels, 2017). Crownfires in subalpine forests commonly yielded evenaged lodgepole pine forests, or lodgepole, subalpine fir (Abies lasiocarpa), and Engelmann spruce (Picea engelmannii) mixes. Crownfires in sub-boreal forests likewise yielded even-aged lodgepole pine, or lodgepole dominated mixes similar to subalpine forests, but also with white birch-Betula papyrifera, white spruce-P. glauca, quaking-Populus tremuloides, and bigtooth aspen- $P$. grandidentata. Although trees with multiple fire-scars indicate the presence of moderate-severity fires, for the most part, moist forests exhibited complex structure with old trees, indicating long fire-return intervals (Courtney Mustafi and Pisaric, 2014; Marcoux et al., 2015). In general, high-severity crownfires dominated in sub-boreal and boreal forests (white and/or black spruce- $P$. mariana), but there was also evidence of abundant tree island remnants and spatial complexity after fires linked to subtle topographic and fire behavior variability and proximity to wetlands and lakes (Andison and McCleary, 2014; Krawchuk et al., 2016). Entangled with fire, episodic insect outbreaks were also common across most forest types (Burton and Boulanger, 2018), and owing to complex successional patterns, most outbreak events were small $\left(10^{0}-10^{2}\right.$ ha) to medium-sized $\left(10^{2}-10^{4} \mathrm{ha}\right)$, but most acres were affected by the largest events ( $>10^{4}$ ha, Aukema et al., 2006).

In BC, burned area is primarily controlled by annual to decadal climate and fire weather; fuels are typically not limiting. However, fuel availability to burn strongly influences fire severity. Recent fires in 2017 and 2018 exhibited extreme behavior and exceeded suppression capabilities across most forest types; more than 1.2 million ha burned in both years. Several lines of evidence reveal that fire exclusion-which reduced forest seral stage heterogeneity (Figure 5B)-and subsequent insect outbreaks have reduced forest resilience and resistance to contemporary fires, with the degree and particular drivers varying among ecosystems. For example, fire scar records from plateau and mountain forests show the near elimination of fires starting in the late $19^{\text {th }}$ - to early $20^{\text {th }}$-centuries (Marcoux et al., 2015; Greene and Daniels, 2017; Harvey et al., 2017). The colonization by Euro-Canadians during this time ended frequent cultural burning by indigenous people (Christianson, 2015;

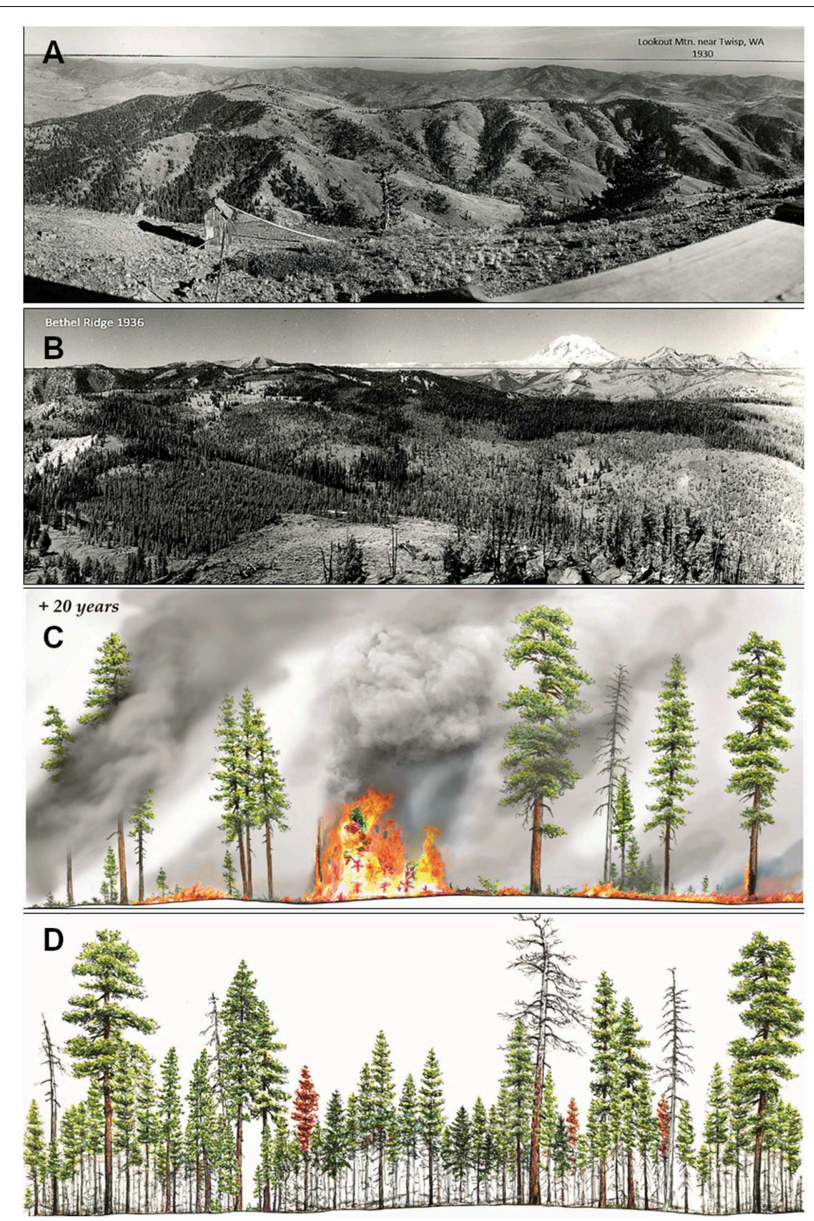

FIGURE 5 | (A) Landscapes were hierarchically nested throughout ecoregions of western North America. Broad-scale physiognomic patchworks formed the upper level. Grasses, herbs, and/or shrubs were the primary fuels, which tended to perpetuate a frequent grass-fire cycle, often yielding mollisols. This broad-scale patchwork functioned as a relatively fast fire delivery system by day, and by night as a fire spread dampening system, where fuel moistures recovered with the night-time relative humidity. Presence of this non-forest-forest patchwork afforded a broad-scale resilience context for the embedded forest. Fires delivered to the forest edge were more often relatively low energy in comparison to modern-era fires. (B) Forest successional landscapes occurred at a meso-scale, and they resided within the larger physiognomic landscape. Forest successional conditions varied by time since fire and reburn frequency. Where reburning was common and reburned patches were small to medium sized, forest successional conditions developed with little or no woody surface fuels, which later led to a low probability of crownfire initiation in the event of a wildfire. With increasing time since fire, forests would encroach on larger grass, shrub, and woodland patches. In areas with long time since fire, forest successional conditions would become more homogeneous, with forest density and layering increasing within and among forest successional patches. Variability in surface fuels and forest successional conditions influenced variability of fire severity and sizes of fire severity patches, which increased both the resistance and resilience of the forest successional landscape. (C) At a relatively fine scale, patches

functioned as small landscapes within the larger successional landscape. Especially in dry and moist mixed conifer patches with low or moderate severity fire regimes, tree regeneration and mortality patterns were clumped and gapped, with both clump and gap sizes roughly following an inverse-J distribution. Frequent to moderately frequent wildfires (e.g., every 5-30 years,

(Continued) 
FIGURE 5 | the illustration shows +20 years since the last fire) would thin out patchy surface fuels fallen since the previous fire, and burn out clumped fuel ladders and individual seedlings, saplings, and poles regenerated since the last fire. This clumped and gapped tree distribution and pattern of fire severity and tree mortality was resilient and self-maintaining under most conditions, and provided resistance to severe fires. (D) Absent frequent fires and regular fuel consumption, patches filled in with regenerating trees, fuel ladders accumulated, and resistance and resilience both collapsed. Panels (C,D) are reprinted with permission of Robert Van Pelt.

Lewis et al., 2018). This, along with fire suppression-preceded by extensive agriculture and livestock grazing-encouraged the expansion of forest cover but reduced flashy fuel continuity and limited fire spread. Absent these fires, changes are evident at patch to broad ecoregional landscape levels. Patch-level changes included accumulation and persistence of dense, understory canopy layers, ingress of seedlings, saplings and poles to form ladder fuels, and accumulation of woody surface fuels (Marcoux et al., 2015; Chavardès and Daniels, 2016). These changes collectively reduced resistance to high severity fires and the likelihood of low- and moderate-severity fires within patches, and increased likelihood of crownfire initiation and spread within and among patches (Figures 5C,D). Understanding and reversing the extent of these developments is a key to restoring resistance and more characteristic patch-level fire behavior.

At local and ecoregional landscape levels, the structure and composition of dry and some moist mixed-conifer forests (interior Douglas-fir, often with lodgepole pine and western larch) has shifted toward closed-canopy, late-seral conditions composed of fire-intolerant species (Douglas-fir, grand fir- $A$. grandis, and subalpine fir), while surface and canopy fuels have become more homogeneous and contagious along elevational gradients (Marcoux et al., 2015; Stockdale et al., 2015; Chavardès and Daniels, 2016). Today, forests are increasingly vulnerable to large spreading crownfires and beetle outbreaks. Restoring open canopy conditions with fire tolerant species and limited surface fuels (Figure 5C), especially in drier topoedaphic settings, is crucial to restoring more crownfire resistant stand and landscape conditions. In both plateau and mountain forests, discerning the relative importance of surface vs. crownfire effects in historical moderate-severity fire regimes remains a work in progress.

Given long fire return intervals and prevalence of crownfires in the historical fire regimes of subalpine, sub-boreal, and boreal forests, fire suppression impacts are less clear within patches relative to landscapes. However, fire suppression along with climate change and management that emphasized widely distributed mature lodgepole pine forest conditions for timber harvest is implicated in the 1999-2015 mountain pine beetle (Dendroctonus ponderosae) outbreak (Carroll et al., 2004; Raffa et al., 2008), which affected 18.3 million ha, and was most severe in sub-boreal forests (Province of British Columbia., 2018). Over the course of the $20^{\text {th }}$-century, fire suppression eliminated most wildfires, which would have maintained heterogeneity in preforest and nonforest lifeform patterns, and forest seral stage, age class, and density conditions (Figures $5 \mathbf{A}, \mathbf{B}$ ), all of which contributed to forest resilience. Absent fires, lodgepole pine trees aged, patches blended with their neighbors, and large forest extents became vulnerable to mountain pine beetle outbreaks (Raffa et al., 2008). Over the last two decades, more than half of BC's merchantable pine volume was killed by bark beetles (731 million $\mathrm{m}^{3}$, Province of British Columbia., 2018), leading to extensive tree salvage operations. Restoring characteristic heterogeneity in lifeform and forest seral stage patchworks is a key to future wildfire and climate change adaptation and resilience of sub-boreal forests.

Fuel hazards perpetuated by modern forest management, including harvests without prescribed burning of silvicultural activity fuels, have reduced forest resistance and resilience to wildfires by amplifying surface fuels and not treating fuel ladders, but hazards could be mitigated (Stephens et al., 2016). BC forest management could benefit from incorporating knowledge of natural fire regimes and cultural burning. Likewise, the BC fire regime classification-developed in the 1980s and 1990s and based on expert knowledge-overstates the role of stand-replacing disturbances in initiating succession, in all but valley bottom and alpine ecosystems (Andison and Marshall, 1999; Daniels and Gray, 2006; Marcoux et al., 2013). This model is used to justify broad application of fire suppression and clearcut silviculture to protect timber supplies, which has led to simplified age-class and patch size distributions, and decreased landscape resilience.

Forest management that is focused on stand-level timber production goals is disconnected from the current reality of increasing landscape vulnerability to wildfires in a changing climate. For example, it is routine practice to remove abundant patches of aspen and birch via silvicide application or precommercial thinning to favor lodgepole pine. These hardwood patches were influential to blocking wildfire flow on the landscape under many fire weather conditions. Their restoration and amplification would be an important wildfire adaptation going forward. The current practice of planting dense lodgepole pine monocultures enhances vulnerability to large-scale future bark beetle outbreaks. Plans to increase planting densities to sequester more carbon will likely result in elevated bark beetle and wildfire-related carbon losses, rather than gains (Hurteau and North, 2009). A diversified provincial wildfire management strategy was introduced in 2012 to protect human life and resource values at risk, and to encourage sustainable, healthy and resilient ecosystems (BC Wildfire Management Branch Strategic Plan., 2012). However, lacking a strong conceptual framework, implementation has been slow, leaving communities vulnerable to both wildfire and climate change.

\section{Inland Pacific Northwest Forests}

The Inland Pacific Northwest (PNW) region displays widely varying biophysical conditions and vegetation types, with areas of Mediterranean and continental climate superimposed on strong west-east temperature and precipitation gradients. Residing in a rain shadow created by the crest of the Cascade and Klamath Mountains, the region hosts several distinct provinces (Figures 2, 6): the Okanogan Highlands (M333), the southern and eastern portions of Northern and Southern Cascade Mountains (M242), the Blue Mountains (M332), and the Upper Klamath Mountains 
(M261). Within the interior portions of these provinces, elevation gradients range from semidesert $(150 \mathrm{~m})$ to alpine $(4,392 \mathrm{~m})$, and dominant lifeform, productivity, growth, and successional patterns are driven by plant-available water (principally from snowpack), temperature, solar radiation, and disturbance.

This interplay of temperature and precipitation gradients, elevation and aspect, created landscapes of intermingled forest type and wildfire regime (Figures 6C,D). Dry forest (pure ponderosa pine and pine mixed with Douglas-fir and/or grand fir) and woodland ( $\leq 20 \%$ tree cover, ponderosa pine, Garry oakQuercus garryana, and western juniper-Juniperus occidentalis) patches typically experienced low- and some moderate-severity burns at 5-25 year intervals (Hessl et al., 2004). Moist forests (western larch, ponderosa pine, Douglas-fir, and grand fir) also experienced low- and moderate-severity burns, but with a greater proportion (20-25\%) at high-severity, owing to often longer (25-50 year) intervals (Hessburg et al., 2007). Cold subalpine forests (Engelmann spruce, lodgepole pine, and subalpine fir mixes) typically experienced moderate- and high-severity burns at 75-150 year return intervals; however, reburning occasionally reinforced low- or moderate-severity fire (Prichard et al., 2017). Combined with extensive aboriginal fires (Boyd, 1999; White, 2015), the result was an intermingling of forest and non-forest cover types, and assorted seral stages (Figures 5A,B).

In addition to driving composition and successional conditions of forests, wildfires created and maintained an ever shifting broad-scale patchwork of grass-, shrub-, and woodland (including pine, oak, and juniper) conditions. Aerial photographs from the early 20th-century show that the combined non-forested area averaged $46 \%$ (range $25-71 \%$ ) of the region (Hessburg et al., 2000, 2016, Table 1; Figures 5A,B, 7). Frequent fires likely reduced total forest area and perpetuated woodlands and grasslands, which consequently supported high fire spread rates and low flame length and fireline intensity (Hessburg et al., 2016). This resilient mosaic that included non-forest types likely delivered fire into dry and some moist forests maintaining tree densities well below carrying capacity (Hagmann et al., 2014). Thus, lifeform patchworks were important for creating and maintaining resilience to disturbance across broad landscapes.

A defining characteristic of the region's forests that conferred resilience was its hierarchical structure. Fire and local climatic conditions maintained dynamically shifting broad-scale patterns of forest and non-forest. Within dry and many moist forest patches, fire, insect, pathogen, and weather disturbances created and maintained fire-resistant, multiaged and unevenly spaced arrangements of individual trees, and small- to moderate-sized tree clumps interspersed with openings of various sizes (Figure 5C, Larson and Churchill, 2012; Churchill et al., 2013). Many low- and moderateseverity fires, and some high-severity fires, left a backbone of medium $(40-64 \mathrm{~cm})$ to large $(>64 \mathrm{~cm})$ diameter, older, fire- and drought-resistant trees (Hessburg et al., 2015), which provided a high degree of genetic diversity and seed sources for regenerating future forests (Hamrick, 2004). These nested conditions provided patch scale resistance to severe wildfires because cross-scale discontinuity of fuels and host trees reduced the likelihood of large crownfires and insect outbreaks. Interspersion and cross-scale linkage among non-forest and forest seral stage conditions, along with tree clumps and openings within forest patches, also provided an exceptional range of habitats in close proximity. Such hierarchical patterning increased plant species diversity of adjacent understory communities, promoted regeneration of fire-tolerant tree species, and increased the duration of snow cover (Lundquist et al., 2013).

Past forest management and fire exclusion have reduced forest resistance and resilience to disturbances and climatic warming. Contributing factors include the forced displacement of aboriginal peoples and termination of their intentional burning; livestock grazing that reduced grass cover and fine fuels, and improved tree establishment; selective logging of large, thick-barked, fire-tolerant ponderosa pine, western larch, and Douglas-fir; and aggressive fire suppression (Hessburg and Agee, 2003; Hessburg et al., 2005). Absent fire, thin-barked and shade-tolerant small-diameter $(10-40 \mathrm{~cm})$ Douglas-fir and grand fir broadly recruited in understories, forming dense, multilayered conditions in most managed dry and moist mixed-conifer forests (Figure 5D). These changes favored expansion of native defoliator (western spruce budworm, Douglas-fir tussock moth), and bark beetle outbreaks (Douglas-fir beetle-D. pseudotsugae, western bark beetle- $D$. brevicomis, and fir engraver beetleScolytus ventralis), and contribute to large influxes of woody surface fuel. On dry plateau and foothill sites, these changes fostered forest encroachment into former grass-, shrub-, and woodlands, and development of often dense multi-layered pine, oak, and juniper forests (Hagmann et al., 2014, 2019). Historical conditions characterized by variable patterns of physiognomic types, forest seral stages, and tree clumps and openings are now homogenized in many places, and the backbone of large, old, fire-tolerant trees has been diminished by logging, bark beetles, and high-severity fires. Collectively, these changes have increased potential for large crownfires and drought-related insect outbreaks (Hessburg et al., 2005), trends that are already witnessed across the region. Reversing these trends and restoring the hierarchical life-form patchworks that once defined this region's forests will be key to restoring multi-scale resilience and resistance. Documenting the natural range of variation in these conditions would inform restorative actions (Landres et al., 1999; Keane et al., 2009).

Today's forests are vulnerable to ongoing climate change (Littell et al., 2009; Cansler and McKenzie, 2014; Reilly et al., 2017). Through expansion of forest area and closedcanopy conditions, patch-level resistance, once instrumental in maintaining low- or moderate-severity fire and localized insect outbreaks, has been eliminated in many places. Large stand-replacing fires have, in some places, shifted broad-scale dominance from conifers to fire-adapted shrubs or hardwoods, while in other places, have synchronized regeneration of fireadapted trees with serotinous cones. In both cases, the effect has been to simplify species composition and perpetuate a high severity fire regime.

The region is at a crossroads; restoring forest resilience to wildfire and climatic warming will require increasing the footprint of treatments and allowing managed wildfires to burn 

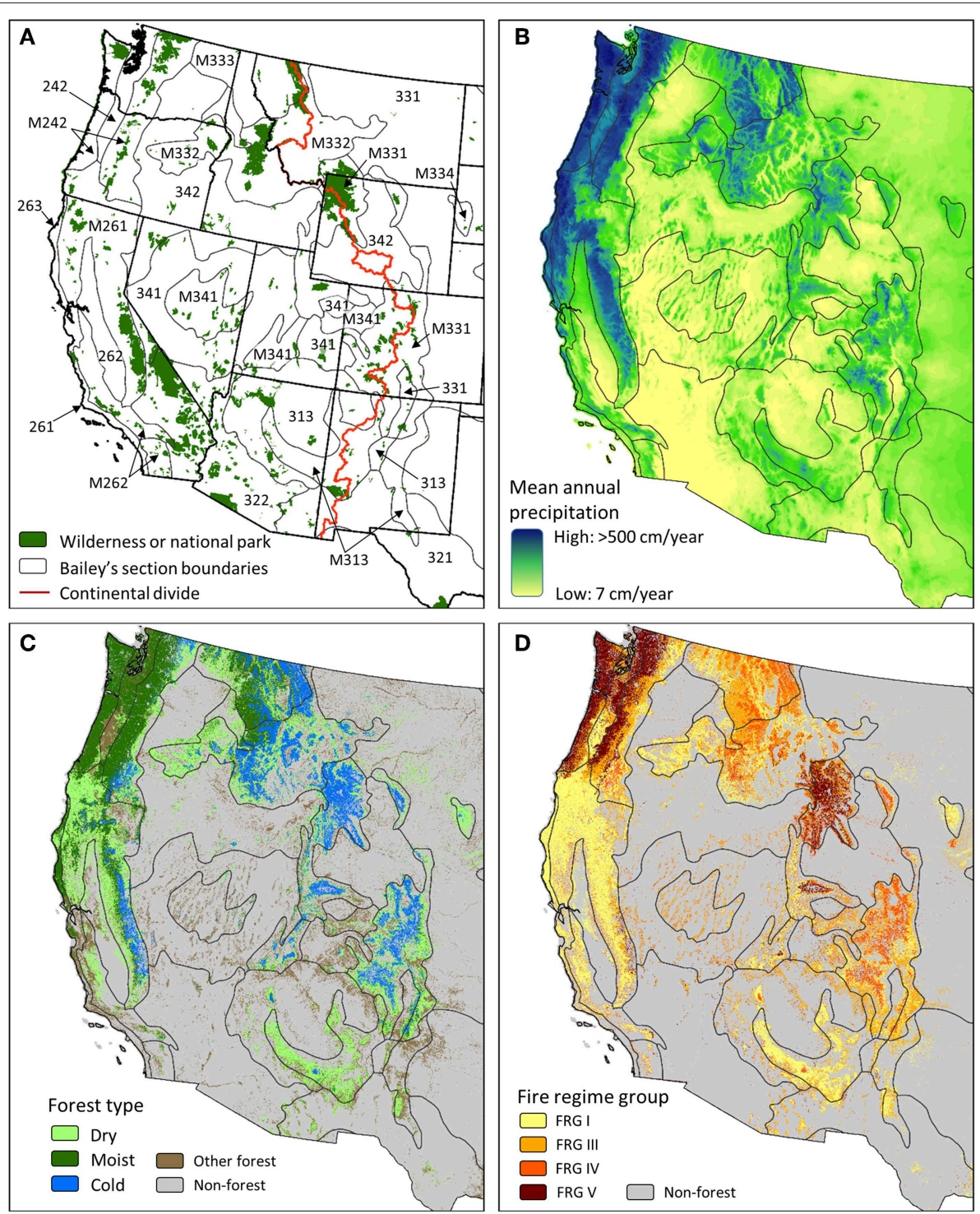

FIGURE 6 | Maps depict (A) protected areas (designated wilderness and national park) and section-level ecoregion boundaries, (B) mean annual precipitation, (C) forest types, and (D) fire regime groups (FRGs) for the contiguous western US. The "other forest" type in panel (C) includes forest types that are not addressed in this paper, such as pinyon-juniper woodlands and riparian forests. FRG classes are FRG I: fire return interval $\leq 35$ years, low and mixed severity; FRG III: fire return interval 35-200 years, low and mixed severity; FRG IV: fire return interval 35-200 years, replacement or high-severity; FRG V: fire return interval > 200 years, any severity. Portions of the study area that extend into Mexico and Canada are not shown because not all datasets are coextensive to these regions. Data sources: Bailey sections -(Bailey, 1998); (B) -(Daly et al., 2008); (C,D) -(Rollins, 2009) (www.landfire.gov).

under certain circumstances to restore fire and the myriad ecosystem functions it supports. Efforts are underway to restore more resilient patterns of forest structure, composition, and fuels, and they are increasing adaptive capacity of many landscapes by reducing forest vulnerability to drought and uncharacteristic high-severity fire events (WA DNR., 2017). However, current efforts are limited by policies that are riskaverse to managed wildfires, mistrust among some partners and stakeholders, insufficient social license to implement treatments, and institutional norms that discourage broad use of prescribed and managed wildfire and mechanical thinning (Spies et al., 2018a). Meanwhile, ongoing aggressive fire suppression facilitates uncontrollable wildfires during periods of extreme fire weather, which drives a majority of fire effects. Adapting the region to a warmer climate will require leadership that enables deep dialogue among community partners about key landscape changes, changes to disturbance regimes, and growing effects of climate change. This information can be used within structured decisionmaking processes (sensu Gregory et al., 2012), whereby tradeoffs in ecosystem structure and function can be considered alongside human community values and needs, resulting in broad landscape-level restoration prescriptions that leave both communities whole. 
TABLE 1 | Area of nonforest, pre-forest (=early seral), and mid- to late-seral conditions in 5 Inland Northwest provinces (Figure 7) shown by potential vegetation group.

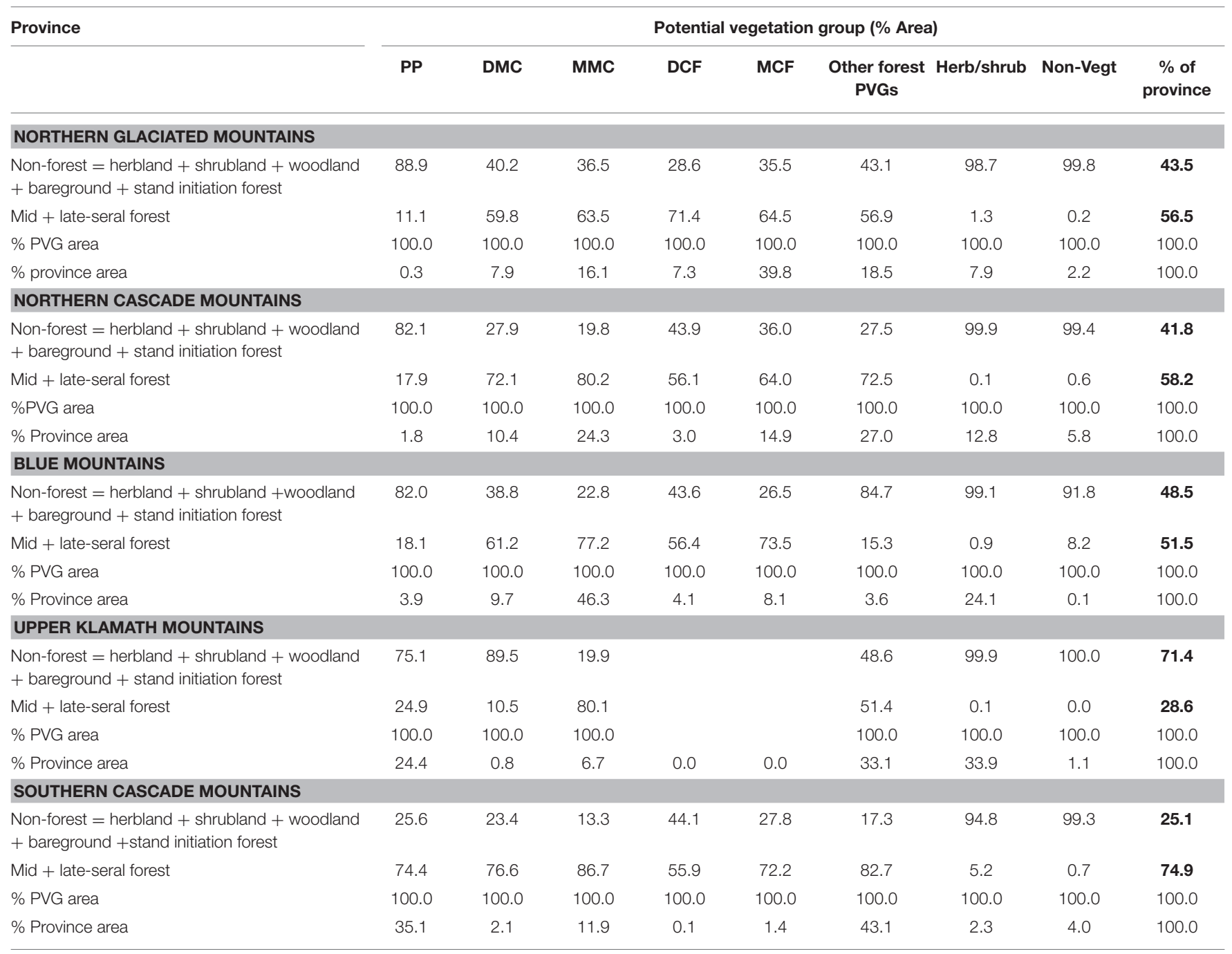

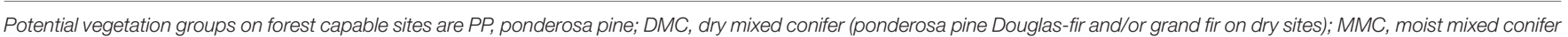

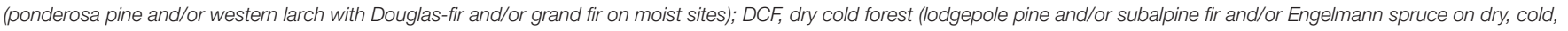

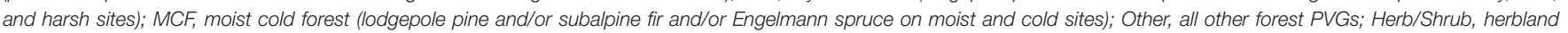

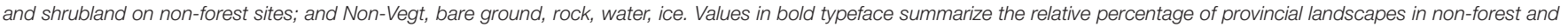
forest conditions.

\section{Northern Rocky Mountain Forests}

The Northern Rocky Mountain (NR) region is distinctive for its broad, high mountain ranges that roughly follow the Continental Divide (Figure 2, M331, M332, M333, M334; and Figure 6A). It is known for its extensive wilderness areas that encourage management of naturally ignited wildfires. Forests of the region can be described in three broad types (Figure 6C): (1) dry pine and dry mixed-conifer (ponderosa pine, often with western larch, Douglas-fir, grand fir, and lodgepole pine), (2) moist mixedconifer (western larch, Douglas-fir, grand fir, lodgepole pine, with western hemlock-Tsuga heterophylla and western redcedarThuja plicata), and (3) cold forests (subalpine fir, lodgepole pine, Engelmann spruce, occasionally with limber pine- $P$. flexilis, whitebark pine-P. albicaulis, and subalpine larch-L. lyalli). Within each of these types, there is substantial compositional and structural diversity associated with local climatic gradients, and topographically mediated differences in fire frequency and severity. The climate of the NR is continental; warmdry summers following warm springs often lead to regionally extensive wildfires (Heyerdahl et al., 2008a; Morgan et al., 2008).

Similar to other interior regions, historical fire regimes varied with forest type (Figure 6D). Dry ponderosa pine and mixedconifer forests experienced frequent (every 5-25 year) low- and moderate-severity fires (Keane et al., 2002); occurrence of standreplacing fire was relatively uncommon. Moist mixed-conifer forests experienced more infrequent (every 25-50 year) mixedand high-severity fires (Arno and Davis, 1981). In cold forests, fires were very infrequent (every 100-300 year, Keane et al., 2002), and often high severity. Across all forest types, stabilizing feedbacks between fire and forest vegetation produced either 


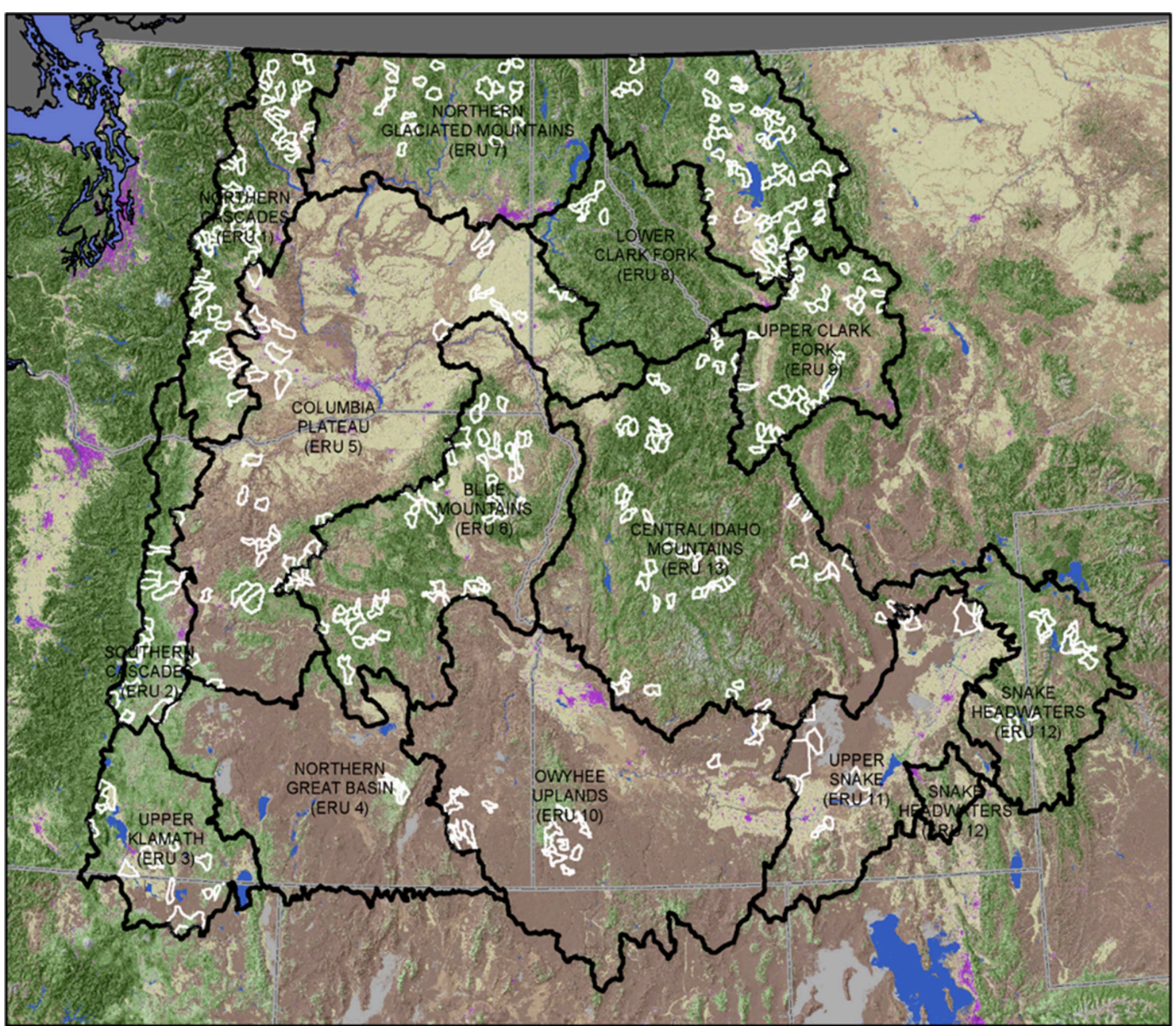

ICBEMP Midscale Sample Distribution

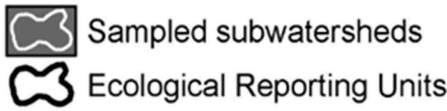

Background image (LANDFIRE, Existing Vegetation Cover (2008)) is provided for spatial context only and does not represent the sampled vegetation condition.

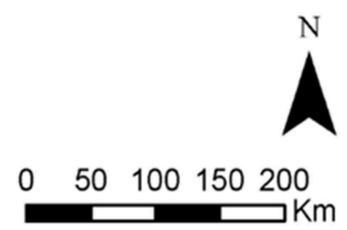

FIGURE 7 | Map of sampled subwatersheds in provinces (Ecological Reporting Units-ERUs) of the Interior Columbia River Basin assessment. Subwatersheds were sampled in a two-stage, stratified random sample of subwatershed conditions of broad province-scale ecological reporting units (ERU's, Hessburg et al., 2000).

a resistant or resilient ecosystem response (Parks et al., 2015), though these feedbacks manifested differently, depending upon whether the fire regime was fuel- or climate-limited, tree species life history traits (Belote et al., 2015), and spatial scale (i.e., patch or landscape). We provide examples of these feedbacks in following paragraphs.

In the dry pine and dry mixed-conifer patches, frequent fire favored fire-tolerant ponderosa pine and western larch, and inhibited in-growth of shade-tolerant and fire-intolerant Douglas-fir. This promoted wildfire resistance within patches through a relatively low density of medium and large diameter trees that were arranged in spatially heterogeneous mosaics of individuals, tree clumps, and openings (Clyatt et al., 2016). The fire regime was primarily ignition driven with frequent fires perpetually limiting fuel accumulation and maintaining a surface-fire dominated regime (Larson et al., 2013) in which fire spread and occurrence were typically self-regulating (Figure 5C, Parks et al., 2015).

Owing to lower fire frequency, moist mixed-conifer forests were composed of fire-tolerant ponderosa pine and western larch intermixed with fire-intolerant species like western hemlock and western redcedar; composition varied a great deal within and among stands. Fires burning under mild to moderate fire weather conditions produced moderate-severity effects, 
reflecting heterogeneous species assemblages and local variability of fuels and topography. Under dry and windy conditions, fires often overrode species traits, resulting in large high-severity burn patches (Belote et al., 2015). Resilience of large forest landscapes to fire was maintained by cross-scale connections between variable fire effects within patches and highly heterogeneous landscape patterns.

In cold forests, tree species exhibit few traits that confer resistance to fires. There, the fire regime was primarily climatelimited; extensive area burned during years with warm-dry summers and low fuel moisture (Morgan et al., 2008; Higuera et al., 2015), and fires could spread rapidly during high wind events. Fire spread and occurrence were more or less selfregulating, conferring a certain amount of resilience to forests at the landscape level; patterns of prior burned and recovering areas decreased the likelihood of fire ignition and spread of subsequent fires for 1-2 decades (Parks et al., 2015, 2016).

Since the 1880s, forests in the NR have been affected by fire exclusion, timber harvest, and interactions with native and nonnative insects and pathogens. As a result of fire suppression and forest management, a once resistant forest composition has shifted away from early seral, shade-intolerant tree species toward late seral, shade-tolerant species (Hessburg et al., 2000; Keane et al., 2002). Dry forest patches have missed several fire cycles, resulting in excessive accumulations of live and dead fuels, and infilling by small diameter, fire-intolerant tree species (Figure 5D). Consequently, contemporary fires are often uncharacteristically large and severe, reflecting decreased forest resistance and resilience. Reversing these trends in dry forests is a key to re-establishing more resistant conditions. In moist mixed-conifer and cold forests, fire exclusion reduced abundance of early- and mid-seral patches, affecting landscape fuel and successional patterns, and species composition. These forests are now more prone to large crownfires than was formerly the case. Re-establishing heterogeneity in forest seral stage conditions is critical to restoring wildfire resilience. Determining the natural range of variation in these conditions will be important to informing restorative actions (Landres et al., 1999; Swetnam et al., 1999; Keane et al., 2009).

Past timber harvest likewise altered dry and moist forest structure, composition, and pattern. Beginning in the 1880s, timber harvests removed large-diameter fire-resistant trees, compounding the effects of fire suppression on forest structure and composition (Hessburg et al., 2000; Naficy et al., 2010). Regeneration harvests of the 1950s and 1960s also affected cold forests, where dispersed clearcutting and associated road building fragmented the landscape, shifted patch-size distributions, and disrupted feedbacks between fire spread and fire history. White pine blister rust profoundly changed moist and cold forests too. Caused by an introduced pathogen, widespread infection resulted in the collapse of western white, whitebark and limber pine populations throughout western North America, altering the composition of moist and cold forests (Maloy, 1997). In cold forests, both lodgepole and whitebark pine have been impacted by climate-driven eruptions of the mountain pine beetle that may be outside the range of historical variability (Logan et al., 2010).
Climate change is an additional stressor of dry, moist, and cold forests. Increasing summer temperatures and decreasing summer precipitation will likely increase area burned (Higuera et al., 2015; McKenzie and Littell, 2017; Holden et al., 2018; Littell et al., 2018). While postfire tree regeneration in recent decades appears sufficient to support forest resilience (Kemp et al., 2016), interactions between fire and drought are increasingly leading to reduced tree regeneration on the driest sites (StevensRumann et al., 2018; Davis et al., 2019), slowing forest succession and causing transitions to non-forest. These changes have the potential to disrupt feedbacks that had maintained forests and their fire regimes for centuries. Dry forests may see reduced tree densities and shifts in species composition, and lower treeline environments may shift upward in elevation (Kemp et al., 2016; Stevens-Rumann et al., 2018). Over longer timeframes, cold and moist forests will likely see more frequent (Figure 6D) but less severe fires (Parks et al., 2018).

Maintaining and enhancing resilience is feasible in the NR. Certainly, shifts in forest types and fire regimes are expected with a warming climate, but fire, especially managed wildfire, will remain key to forest resilience in the region. The relatively sparse human population provides ample opportunities for managed wildfires. In backcountry areas, a history of managed wildfires has maintained stabilizing feedbacks that promote resilience at stand and landscape levels (Larson et al., 2013; Parks et al., 2015). In areas where these feedbacks have been disrupted, managed wildfire may be integrated with restorative treatments to reinforce these more stabilizing influences (Hessburg et al., 2015).

\section{Southern Rocky Mountain Forests}

The Southern Rocky Mountains region (SRM; M331, Figures 2, 6) extends from southern Wyoming through Colorado, and into northern New Mexico. Forests span elevations from 1,600 to $4,000 \mathrm{~m}$ and include steep, dissected mountains, high plateaus, and intermountain basins. Varied topography, prevailing westerly winds, and monsoonal precipitation create wide variability in climate, vegetation, and fire regimes.

Resistance and resilience of SRM forests to wildfires varied widely according to the historical fire regime. In lower montane ponderosa pine woodlands, fires were frequent, and most were surface fires; their intensity and extent were fuel-limited (Sherriff et al., 2014; Brown et al., 2015). Frequent fires were lethal to seedlings and saplings, but not mature trees, resulting in a relatively resistant, open park-like structure, with relatively slow tree attrition and recruitment (Figure 5C).

In dry mixed-conifer forests (ponderosa pine and Douglas fir, with lodgepole pine and aspen), the fire regime was more complex, including low-, moderate-, and high-severity patches, which resulted in highly variable patchworks of tree species, sizes, and densities, along with non-forest openings (Sherriff et al., 2014; Battaglia et al., 2018). Dry mixed-conifer forests were characterized by high structural diversity, and included a mix of species that resulted in a gradient of resistance and resilience to fire. For example, thick-barked ponderosa pine and Douglas-fir enhanced the resistance of these forests to lowseverity fires, while the regeneration strategies of aspen and 
lodgepole pine made these forests resilient to high-severity fires. Infrequent occurrence of large and severe fires, often associated with extreme drought, contributed to landscape heterogeneity by creating large, long-lasting non-forest openings (Brown et al., 1999; Huckaby et al., 2001). As in other ecoregions, diversity of lifeform patterns, nested forest successional patterns and varied species composition likely influenced high spatial diversity in the mix of fire and forest insect outbreak severity.

Moist mixed-conifer forests of the upper montane zone consist of Douglas-fir, white fir, lodgepole pine, aspen, Engelmann spruce, and subalpine fir. These forests were also characterized by a variable severity fire regime, including low-, moderate-, and high-severity patches, which resulted in heterogeneous patterns of species assemblages and seral stage conditions (Tepley and Veblen, 2015). Lodgepole pine and mixed Engelmann spruce and subalpine fir forests experienced infrequent (100-300 ${ }^{+}$years) high-severity fires (Higuera et al., 2014; Calder et al., 2015), typically under conditions of extreme drought (Schoennagel et al., 2005). While lodgepole pine typically recovered quickly after fire (Dunnette et al., 2014), spruce-fir forests recovered more slowly-often taking decades to more than a century.

Modern-day SRM forests reflect complex patterns of human impact, including widespread intentional burning during severe $19^{\text {th }}$-century droughts, followed by $20^{\text {th }}$-century fire exclusion, domestic livestock grazing, and logging (Kitzberger et al., 2007; Sherriff et al., 2014; Battaglia et al., 2018). In the lower montane pine zone, fire exclusion has resulted in increased forest density and higher fire severity. In upper montane moist mixed-conifer forests, widespread high-severity fires and $20^{\text {th }}$-century logging have created forests with small diameter trees and elevated fuel continuity (Sherriff et al., 2014; Battaglia et al., 2018). In high elevation lodgepole pine forests, widespread burning and logging in the late $19^{\text {th }}$ century created bark beetle susceptible forests, which have experienced episodic large outbreaks during recent droughts (Chapman et al., 2012; Hart et al., 2015).

Warming temperatures, drought, and below average snowpack since the late-1990s have resulted in increased wildfire and bark beetle activity across all forest types. Moreover, there has been a steady decline in the resilience of ponderosa pine and dry mixed-conifer forests attributable to removal of seed sources by large high-severity fires, and moisturelimited regeneration at low-elevation sites (Stevens-Rumann et al., 2018). A warmer, drier climate in the $21^{\text {st }}$-century exposes these forests to an increasing number of large, high-severity fires. Limited seed sources and drought will likely slow or limit recovery, resulting in some conversions from forest to non-forest conditions after fires (Andrus et al., 2018). Lower elevation forests are also increasingly susceptible to invasion by invasive annual grasses which contribute to even greater fine fuel continuity and more frequent grass-driven fires.

In contrast, there is resilience to insect outbreaks in some dry and moist mixed-conifer forests due to the presence of advanced hardwood or conifer regeneration (Pelz et al., 2015). Thus, while wildfires and bark beetle outbreaks will continue to increase in frequency and severity with a warming climate, negative feedbacks of short-term aspen dominance and greater abundance of young beetle-resistant trees will likely buffer the extent and frequency of some future fire and beetle disturbances (Hart et al., 2015).

Recent and ongoing declines in forest resilience under climate warming have major societal implications (Calkin et al., 2014). Water is a precious commodity in the arid West, and many of the rivers that supply water to the SRM originate in these forests. Severe wildfires increase soil erosion and sedimentation of water supply systems, necessitating expensive remediation. Exurban development into forests continues at a brisk pace, resulting in continued pressure to suppress all fires.

Current forest management in the SRM is informed by a robust understanding of forest resilience and resistance mechanisms, and of the historical ecology. This knowledge is being implemented to address problems posed by rapid exurban development into fire-prone ecosystems. Prescribed burning programs to reduce surface fuels and maintain dry forest treatments are widely accepted (Fernandes and Botelho, 2003), but often limited in extent due to wildlandurban interface and smoke concerns, as well as costs of removing non-merchantable trees (Addington et al., 2018). In backcountry areas, managed wildfire is an increasingly used and accepted practice to increase landscape heterogeneity, improve resilience, and buffer against subsequent fires and bark beetle outbreaks. Efforts are underway to increase landscape resilience by increasing landscape heterogeneity with variable-density thinning, creating openings in forests, and by favoring drought- and fire-adapted tree species, but many challenges remain.

\section{Klamath and Southern Cascade Mountain Forests}

The Klamath and Southern Cascade Mountain regions (Figures 2, 6, M261) are influenced by a Mediterranean climate, with strong west-east precipitation and temperature gradients. The modern climate was established ca. 3,000-4,000 year ago, and climate has been the dominant driver of fire activity throughout the Holocene (Briles et al., 2008; Skinner et al., 2018). Elevation gradients in the deeply dissected Klamath Mountains are strong, controlling local and regional climate patterns. Prominent ridge systems occur between 1500 and $2200 \mathrm{~m}$, and elevations range from 30- to 2755-m (Skinner et al., 2018). With volcanic peaks rising from basalt plateaus, the Southern Cascade Range is geologically younger than the Klamath Mountains, and elevations range from $60-\mathrm{m}$ in the foothills to 4,317-m on Mt. Shasta (Skinner and Taylor, 2018). In both regions, forests are dominated by conifers but often include a mixture of evergreen and deciduous hardwoods. Fire-dependent shrubs are common in both regions, but evergreen hardwoods are more prevalent in the Klamath Mountains.

The Klamath Mountains harbor some of the most diverse forests in the western US (Michael et al., 1993). There, high spatio-temporal variability in fire regimes at local and landscape 
levels contributes to a regional biodiversity hotspot. Prior to Euro-American settlement, topography strongly influenced fire regime characteristics, with elevation establishing gradients in fire frequency from high to low, across dry, mesic, and cold forest types, respectively. In dry ponderosa pine and dry and moist mixed conifer forests (Figure 6C), fires were compartmentalized by ridgetops, north to south aspect changes, riparian zones, and surface lithology. Dry mixed conifer forests included ponderosa pine mixed with Douglas-fir, white fir- $A$. concolor, incense cedarCalocedrus decurrens, western juniper-Juniperus occidentalis, and blue-Quercus douglasii, Garry-Q. garryana, or California black oak-Q. kelloggii, or gray pine-P. sabiniana. Moist mixed conifer forests included ponderosa or Jeffrey pine mixed with Douglasfir, white fir, Pacific madrone-Arbutus menziesii, chinquapinChrysolepsis spp., canyon live oak-Quercus chrysolepis, bigleaf maple-Acer macrophyllum, black oak, Pacific dogwood-Cornus nuttallii, and/or sugar pine-P. lambertiana. These compartments burned with similar frequency, yet often in different years. However, in drought years, fires burned across neighboring compartments and landscapes, often unabated, highlighting the varied contributions of bottom-up and top-down controls on fire regimes (Taylor and Skinner, 2003; Taylor et al., 2008). Steep and often narrow ridgetops created contrasting conditions leading to variation in fire behavior and effects. Additionally, the upper third of slopes and ridgetops experienced higher proportions of high-severity fire, and valley bottoms and lower slopes, the lowest (Figure 8). The distribution and persistence of fire-dependent shrublands and serotinous cone tree speciessome which are narrowly endemic-are linked to landscape level fire severity patterns. Fuel discontinuities in high-elevation glacially-carved landscapes contributed to localized fire refugia, occupied by fire sensitive species and some of the richest conifer assemblages worldwide (Skinner et al., 2018). However, in the gentler topography of the Southern Cascades, common lowand moderate-severity fires were seldom constrained by terrain. Severity patterns instead were influenced by variation in fuel and weather (Skinner and Taylor, 2018).

Fire regimes changed after Euro-American settlement and the advent of fire suppression. In dry and mesic forests, frequent relatively small fires became less frequent and larger, with less change in low frequency fire regimes of cold forests. With suppression and fire exclusion, the reduced fire frequency and extent caused cross-scale changes in patterns of vegetation and fuels, which were most obvious in dry and mesic forests (Figure 9). An exception to this general pattern occurs in areas of ultramafic bedrock with species that tolerate nutrient poor soils, where vegetation and fire regimes have remained stable for millennia despite climatic changes (Briles et al., 2008; Skinner et al., 2018). Before fire suppression, fires of variable severity, but tending toward low- and moderateseverity, created high spatial complexity in forest openings, and generally more open-canopy conditions than are typical today. This self-reinforcing heterogeneous pattern enhanced forest resilience but has been replaced by more uniformly dense and layered forests, with more conifers, fewer hardwoods, smaller and fewer openings, and higher fuel connectivity at all levels.

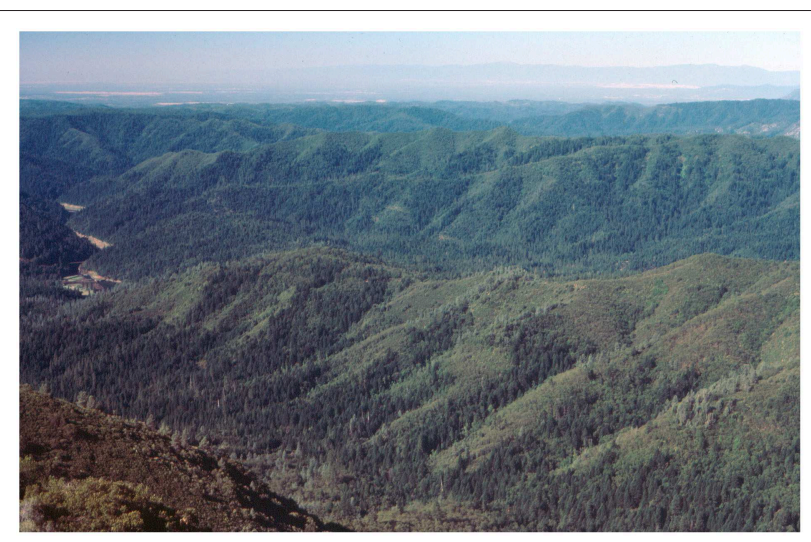

FIGURE 8 | Spatial variation in vegetation patterns related to slope position and fire severity relationships in dry and mesic forests in the Klamath

Mountains. Topography creates contrasting conditions in fire behavior and effects; the upper third of slopes, drier aspects, and ridgetops tended to experience higher proportions of high severity fire, while valley bottoms, cooler aspects, and lower slope positions experience the lowest (Photo: Carl Skinner).

Vegetation changes related to fire exclusion and forest management have consequences for patterns of forest resilience and resistance to fire. For example, modeling experiments show that certain conifers increased their abundance and range in dry and mesic mixed forests in response to fire exclusion, and that their current distribution is misaligned with current climate and disturbance regimes (Serra-Diaz et al., 2018). Misalignment has altered stability of fire-vegetation feedbacks with potential cumulative effects on vegetation patterns at local to ecoregion levels. Altered fire-vegetation dynamics are evident in the effects of large wildfires that have burned in the Klamath and Southern Cascade Mountains over the last several decades. For example, in the Klamath Mountains, spread of high-severity fire into moistcold Shasta red fir-A. magnifica, western white pine- $P$. monticola, and/or mountain hemlock-Tsuga mertensiana and cold forests (western white pine, Jeffrey pine, whitebark pine, foxtail pine$P$. balfouriana, mountain hemlock, and/or curl-leaf mountainmahogany-Cercocarpus ledifolius) has reduced forest resilience at locallevels, with the potential to extirpate fire-sensitive Brewer's spruce-P. breweriana (Skinner et al., 2018). Though there is no overall trend in total area burned at low, moderate, and high severity in large fires, there is a clear trend of increasing fire sizes along with increasing sizes of high-severity burned patches (Skinner et al., 2018). In contrast, area burned in dry and mesic forests has increased as has area burned at high severity in the Southern Cascades (Skinner and Taylor, 2018). Stand replacing fires in dry and mesic forests of the Southern Cascade and Klamath Mountains have shifted dominance from conifers to hardwoods and shrubs (Lauvaux et al., 2016; Tepley et al. 2017). High-severity reburns in flammable shrublands will likely promote long-term vegetation shifts from forests to shrublands at local, landscape and ecoregion levels (Tepley et al., 2017; Miller et al., 2018; Serra-Diaz et al., 2018; Skinner et al., 2018). Continued invasion by non-native annual grasses will further contribute to these shifts. 


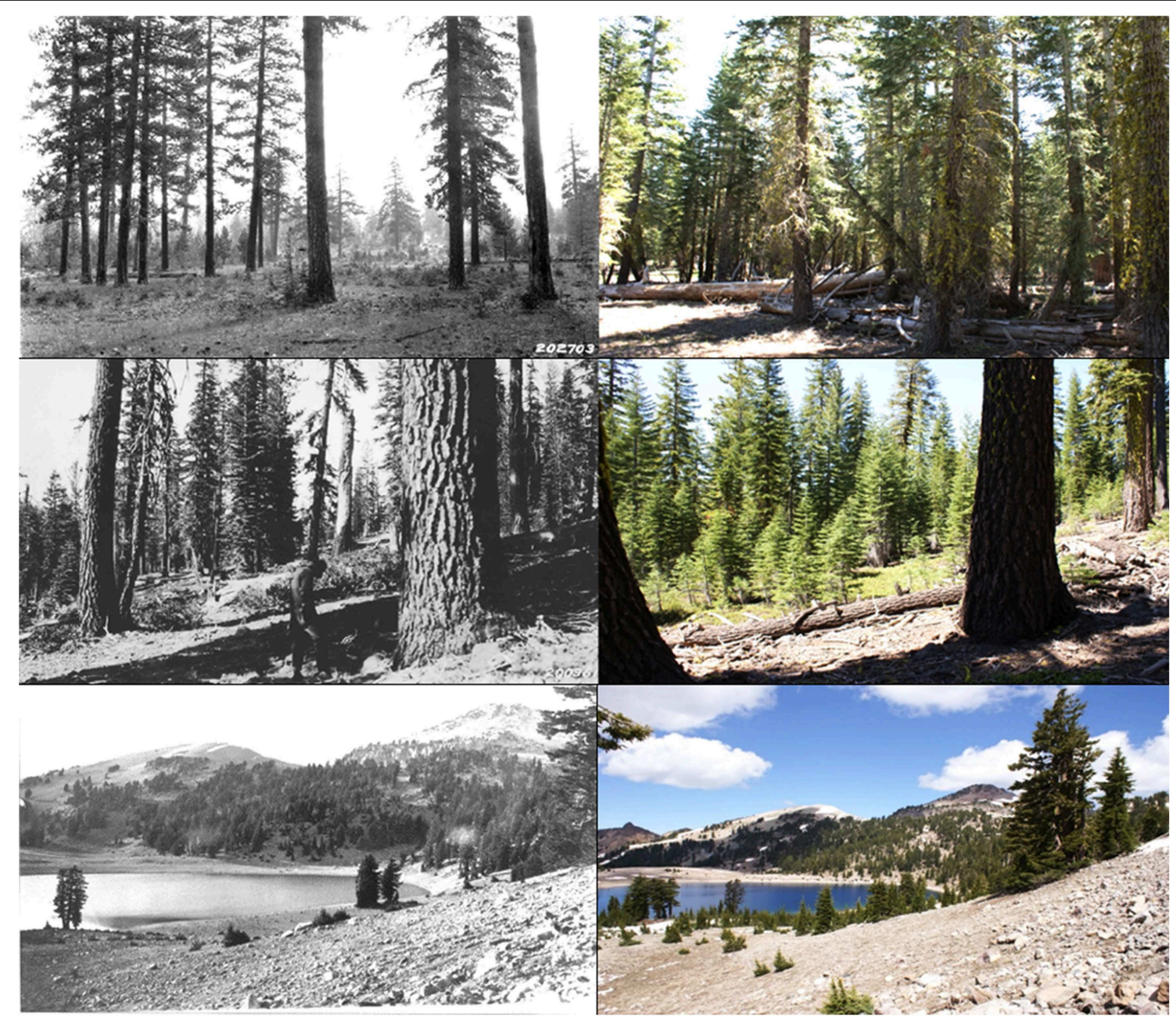

FIGURE 9 | Twentieth century forest changes in dry, mesic, and cold conifer forests in repeat photographs along an elevation-fire frequency gradient in the Southern Cascades, California. Fire regimes changed across the region after 1905 when fire suppression was implemented. Changes in tree density and species composition caused by fire suppression are more evident in dry (Top left, Weislander, 1925; Top right, Alan Taylor, 2008) and mesic (Middle left, Weislander, 1925; Middle right, Alan Taylor, 2009) forests that burned more frequently, than in cold (Bottom left, Blair, 1934; Bottom right, Alan Taylor, 2009) forests. Forests have not been logged and the photographs were taken in Lassen Volcanic National Park at referenced markers. Additional details on fire regimes and forest changes in the Southern Cascades can be found in Skinner and Taylor (2018).

While $20^{\text {th }}$-century vegetation changes are regionally significant in the Klamath Mountains, they have not overridden topography as a primary structuring influence (Estes et al., 2017; Grabinski et al., 2017). Currently, areas burned at low and moderate severity still outpace those burned at high severity, and less severely burned areas exhibit self-reinforcing behavior (Grabinski et al., 2017; Skinner et al., 2018), buffering somewhat against projected climate-induced increases in aridity, fire activity, and conifer regeneration failure (Miller et al., 2018; Serra-Diaz et al., 2018). In addition, a recent history of longduration low- and moderate-severity wildfires reveals a region well-suited to strategically planned and intentionally managed wildfire to reduce the ongoing historical fire deficit and reduce the occurrence of high-severity fire events (Serra-Diaz et al., 2018; Skinner et al., 2018).

\section{Sierra Nevadan Forests}

Prior to Euro-American settlement, plant-available water and wildfire were primary drivers governing forest dynamics in the Sierra Nevada (SN, North et al., 2016, Figures 2, 6, M261). Because $85 \%$ of annual precipitation occurs as snow in this region, water availability largely depends on winter snowpack. Overall, California experiences one of the most spatially variable precipitation regimes in the US. Spatial variability in plantavailable water is influenced by landform position, soil depth and water holding capacity, and strongly influences forest type, productivity and cover (Lydersen and North, 2012). In turn, spatial variability of water availability also influences the frequency and severity of fires.

Under pre-settlement era conditions, most SN montane forests supported fire regimes characterized by frequent 
low- to moderate-severity fires (every 11-16 years) in pure ponderosa, Jeffrey pine and mixed-conifer forests (ponderosa or Jeffrey pine mixed with sugar pine, incense cedar, white fir, Douglas-fir, giant sequoia-Sequoiadendron giganteum, black oak, canyon live oak, dogwood species-Cornus spp., mountain misery-Chamaebatia foliolosa, ceanothus-Ceanothus spp., and manzanitas-Arctostaphylos spp.). Owing to high fire frequency, extensive burning in these fire regimes was fuelrather than climate-limited. Stand-replacing high-severity fire was a component of the historical fire regime, but only made up 5-10\% of any given landscape (Safford and Stevens, 2017). Spatial patterns of stand-replacing fires consisted of many small $(<4 \mathrm{ha})$, and few mid-sized patches $(<100 \mathrm{ha}$, Safford and Stevens, 2017). Patterns of low-, moderate-, and high-severity fires-along with available moisture and productivity gradientscreated considerable variability in landscape-level seral stage conditions (e.g., Collins et al., 2015). At the level of individual forest patches, fire and localized mortality from drought and bark beetles created heterogeneous conditions characterized by variable-sized tree clumps, individual trees, and openings, a pattern found in many frequent-fire forests (Figure 5C, Lydersen et al., 2013).

Variability in fuel and seral stage conditions at patch and landscape levels produced a range of vegetation structures, densities, and fuel discontinuities that made $\mathrm{SN}$ forests relatively resistant to large-scale mortality from wildfire and drought stress. Fire histories and tree-ring reconstructions of past droughts also suggest pre-settlement era forests were resilient to these disturbances, showing little evidence of type conversion or largescale mortality (Swetnam and Baisan, 2003).

In the absence of fire, many modern-era $\mathrm{SN}$ forests now have uncharacteristically high tree densities and fuel loads (Figure 5D). Additionally, there is much greater surface and canopy fuel continuity evident at patch to landscape levels (Lydersen and Collins, 2018), resulting in greater potential for crownfire initiation and spread. Empirical evidence from hundreds of fires in SN forests demonstrates standreplacing patches have become larger and less constrained by topography in recent years, and that the likelihood of tree re-establishment has diminished (Stevens et al., 2017). Beyond fire impacts, modern high-density forest conditions are susceptible to drought and bark beetles (Young et al., 2017), creating large areas of tree mortality and increased surface fuel loading.

The combination of a warming climate, drought, invasive annual grasses (in oak woodlands), increasing occurrence of extreme-fire weather events, and continued fuel accumulation is leading to more frequent and extensive fires in the SN. Climatically driven changes in wildfire could overshadow the direct effects of climate change on tree species distributions and migrations. Increased fire size, which often results in larger and more simply shaped stand-replacing patches (Stevens et al., 2017), may lead to abrupt changes in tree species compositions, reduced extent of old forest conditions, and habitats for associated species (Safford and Stevens, 2017).

Subalpine forests (including whitebark, lodgepole, and western white pine, mountain hemlock, western juniper, and
Sierra juniper-Juniperus grandis) in the SN are largely structured by abiotic factors including snowpack depth and persistence, wind, minimum temperatures, evaporative stress and short growing season (Millar and Rundel, 2016). Higher minimum temperatures may be contributing to increased tree establishment and stand density, although there has been little change in species composition (Dolanc et al., 2013). There are few studies of historical fires in subalpine forests, however, it appears that wildfires shaped seral stage patch dynamics of local and regional landscapes, but fire was apparently not a dominant driver of within-patch dynamics. At higher elevations, rock outcrops, shallow soils, and fine-scale microclimate variability create highly diverse composition and structure (short stature krummholz cushions to $30-\mathrm{m}$ tall trees), diversifying subalpine ecosystems and making them more resilient to climatic and biotic stresses. However, recent research documents increased mortality of large-diameter trees since the 1930s that is potentially associated with increased water deficits and vulnerability to insects and pathogens (Dolanc et al., 2013).

Prescribed burning and managed wildfire are effective restoration treatments for creating heterogeneity in seral stages that historically conferred resilience to many $\mathrm{SN}$ forests. However, these treatments are underutilized in altered SN forests, as there are numerous constraints to intentional burning (North et al., 2012). These include impacts to local communities from smoke, reduced recreational opportunities, inadequate personnel to conduct burns, liability for fire escapes, and risk-averse policies and institutions (North et al., 2015). Mechanical treatments are also effective for ecological restoration and promoting forest resilience (Collins et al., 2014). However, as with fire use, there are numerous constraints that limit the extent of treatments. Current management practices include fire suppression, which paradoxically allows occurrence of only large wildfires that escape containment during extreme fire weather conditions. Such fires generally do not restore forest resilience but instead increase the likelihood of burning again at high-severity (Coppoletta et al., 2016). Actively suppressing all wildfires except those that escape containment can entrench homogenous forest or non-forest conditions, and fails to restore the heterogeneity that supports ecosystem diversity and resilience.

\section{Southwestern US Forests}

In Southwestern (SW) US forests (Figures 2, 6, M313, 313, M331), species composition, structure, and spatial distribution are shaped by climate influences on wildfire regimes and forest productivity. Climate affects the spatial distribution of forests through synoptic (broad-scale) regeneration, growth, mortality, and disturbance events. Topographic gradients in temperature, solar radiation and water availability increase the spatial complexity of forest structure and composition (O'Connor et al., 2017). Regionally, area burned is synchronized with wet-dry phases of the El Niño-Southern Oscillation (ENSO). Increases in area burned are partially driven by increased plant growth during wetter years, which increases landscape connectivity of fine fuels (Swetnam et al., 2016). Within-year fire season length varies as a function of time between winter snowmelt and the summer monsoon (Westerling, 2016). Low- to mid-elevation forests are 
available to burn each year, whereas cool, higher-elevation forest availability to burn is driven by snowpack longevity and extreme fire weather.

Southwestern forests are continuously shaped by interactions among climate-related stressors, including fire, drought, and insect outbreaks (Allen, 2007; Williams et al., 2013). Climatic conditions and combined natural and human-caused ignitions resulted in fire frequency generally varying as a function of elevation over the historical period (Hurteau et al., 2014; O'Connor et al., 2017). In low- and mid-elevation forests, dry lightning preceding summer rains and aboriginal fire use provided abundant ignitions (Swetnam et al., 2016); resulting fires created heterogeneous forest structures at patch to landscape levels. At higher elevations, low fire frequency and faster buildup of high fuel loads resulted in larger moderate- and highseverity fire patches, which created complex seral stage patterns (Margolis et al., 2011).

At low and mid elevations, dry ponderosa pine and dry mixed-conifer forests (ponderosa pine with Douglas-fir, white fir, occasionally with southwestern white pine, limber pine, often with quaking aspen, and/or Gambel oak) historically exhibited mean fire return intervals (FRIs)-ranging from 2 to 16 year-that maintained relatively open-canopy conditions with well-developed understory plant communities (Hurteau et al., 2014). Frequent fires and resultant open-canopy structures (Figure 5C) enabled these forests to resist high-severity fire, while higher-elevation mesic mixed-conifer forests (Douglasfir with quaking aspen, white fir, southwestern white pinePinus strobiformis, and blue spruce- $P$. pungens), with mean FRIs of 3-25 year, experienced low- and mixed-severity fires (Hurteau et al., 2014). Spruce-fir forests (Engelmann spruce, occasionally with blue spruce, corkbark subalpine fir-Abies lasiocarpa var. arizonica, Douglas-fir, white fir, limber pine, and bristlecone pine-Pinus aristata) at the highest elevations typically experienced infrequent stand-replacing fires (Margolis et al., 2011; O'Connor et al., 2017).

By ca. 1900, land-use change and fire suppression had interrupted fire regimes across the Southwest, followed by episodic climate conditions favoring tree establishment and growth (Covington and Moore, 1994). Over the $20^{\text {th }}$ century, these factors combined to increase forest area, density, layering, and surface fuel accumulations, resulting in greater homogeneity of highly-connected forest with high fuel loads. This widespread structural homogenization has made SW forests more susceptible to high-severity fire at patch, landscape, and ecoregion levels (Allen, 2007, 2014). Also, regional drought since $\sim 1998$ and increasing temperatures from ongoing climate change are exacerbating tree mortality (Williams et al., 2013). For example, the area burned by wildfire has increased by $1,200 \%$ over the past 40 years as temperature has increased (Westerling, 2016). Increasingly large patches of stand-replacing fire are driving these homogenous forests toward non-forest conditions as conifer seed sources become limited and grasslands (including invasive annual grasses) and shrublands expand. In addition, densified forests that have not recently experienced fire are also widely affected by drought-induced growth stress and tree mortality (Williams et al., 2013). The combined effects of higher temperatures, reduced precipitation, and larger patches of highseverity fire are limiting postfire conifer establishment (Shive et al., 2013; Hurteau et al., 2014; Ouzts et al., 2015; Coop et al., 2016). The interactions among climate and land-use changes that drove widespread forest structural homogenization have set up SW forests for significant spatial contraction after fire (Allen, 2014).

Prior to fire-exclusion, forest structural heterogeneity was central to maintaining ponderosa pine, mixed-conifer, and spruce-fir forest resilience and resistance to wildfires. Forest densification and homogenization via fire-exclusion-coupled with ongoing climate change-has greatly reduced resistance to high-severity fire in many SW ponderosa pine, mixedconifer, and even spruce-fir forests (Allen, 2014; O'Connor et al., 2017). Empirical evidence suggests that lower total precipitation and higher variation in interannual precipitation in low-elevation forests has increased the likelihood of transition from forest to non-forest conditions (Hurteau et al., 2014). With increasing large-fire frequency (Westerling, 2016), we can expect reduced postfire forest resilience driven by reduced conifer seed-rain and drier climate conditions (Coop et al., 2016).

Both the ecological consequences and benefits of fire as a function of fire-severity have long been recognized in the SW US (Swetnam et al., 2016). Reconstructions of historical fire-maintained forest structure, especially in ponderosa pine, have informed many current management practices that seek to increase structural heterogeneity through mechanical thinning and reintroduction of surface fire. However, similar to the challenges faced in other fire-prone regions, treatment costs, public support, and topographic constraints have limited the pace and scale of that re-introduction. In remote backcountry areas (e.g., the Gila Wilderness), management of natural fire ignitions to maintain this important process has been in place for decades, and such "wildland fire use" is becoming increasingly common region-wide. Recent wilderness research re-affirms that landscapes with more characteristic fire regimes are better able to self-regulate fire size and severity, even as the climate changes (Parks et al., 2014, 2015).

Questions remain regarding what can be gained by restoring fire to some of the driest SW forests. As temperatures continue to rise, and interannual precipitation variability remains high, the potential exists for ongoing, widespread tree mortalitya phenomenon that has occurred during prior hot droughts (Allen, 2007; Williams et al., 2013). Further, increasingly large high-severity fires can trigger vegetation shifts in concert with ongoing climate change (Allen, 2014; Coop et al., 2016; Parks et al., 2019). The societal implications of large, high-severity fires are already being realized in terms of impacts on water supply (Smith et al., 2011), carbon sequestration, and air quality; more managed fire can ameliorate all of these impacts (Hurteau et al., 2014). Yet, it remains to be seen how restoring historical forest structures and frequent-fire regimes to these ecosystems will affect projected rates of climate-induced forest loss from growing regional drought stress (Williams et al., 2013), and how Southwestern topographic variability may moderate regional climate change and create tree refugia in cooler and wetter 
sites. Regardless of these uncertainties, restoring forest structural heterogeneity provides a strong bet-hedging strategy against ongoing climate-change impacts.

\section{Northern Baja California Forests (Mexico)}

The Baja Peninsula of California (Figures 2, 6, M262, M263) is traversed by the Peninsular Ranges, a north-south trending backbone of westward-tilted fault blocks that stretch from southern California to Cabo San Lucas. In the northern part of the Mexican Peninsular Range reside the Sierra Juarez (SJ) and Sierra de San Pedro Mártir (SSPM) conifer forests (Bullock, 1999). The SJ and SSPM forests are mainly underlain by granitic lithologies, which yield well-drained soils with limited water holding capacity (Stephens and Gill, 2005; Fry et al., 2018). To the west, the Sierras slope gently toward the Pacific coast, on the east they are bounded by steep, tall escarpments that abruptly drop to the Sonoran desert. Climate in the northern Baja Mountains is Mediterranean, with a stronger summertime monsoonal influence than is experienced in similar Sierra Nevada (SN) sites farther north. Winters are cool and moist, summers are warm and dry. In the SSPM, annual precipitation ranges from 400 to $700 \mathrm{~mm}$, mostly falling as winter snow, however, $10-20 \%$ of annual precipitation falls as rain in summer due to the North American monsoonal influence (Minnich et al., 2000; Skinner et al., 2008; Dunbar-Irwin and Safford, 2016).

The Kumiai, Pai Pai and Kiliwas aboriginal cultures inhabited northern and central Baja California before the arrival of European settlers (Shipek, 1993); a nomadic lifestyle permitted them to follow resource availability with the changing seasons. According to Barbour et al. (1993), fires were intentionally set by aboriginals to open shrublands for hunting and passage, and to increase grass production. In the summer, Kiliwas and Pai Pai moved to high-elevation meadows in the Peninsular Ranges to hunt and collect seeds, but snowy winters did not permit year-round habitation (Meigs, 1935; as cited in Stephens et al., 2003). After the founding of the mission of San Pedro Mártir in 1794, livestock became a seasonal presence in the conifer forests and montane meadows. From 1924 to 1965 there were 6,000 sheep in the SSPM, but sheep have been almost entirely replaced by cattle today (Stephens et al., 2003). Livestock use of national park lands is technically prohibited in Mexico, but hundreds of cattle from local ejidos (communal farmlands or cooperatives) continue to use SSPM ranges for summer forage.

The Peninsular Ranges in the northern Baja California (north of $30^{\circ}$ latitude) support conifer forests above $1,500 \mathrm{~m}$ in the SJ, and above $1,800 \mathrm{~m}$ in the SSPM. The SJ is dominated by open forests and savannas of Parry pinyon and Jeffrey pine, often with an understory of sagebrush-Artemisia spp. Forests of the SSPM occur at higher elevations (up to $3,096 \mathrm{~m}$ at Picacho del Diablo) and support most of the tree species that are typical of southern California yellow pine (syn. Jeffrey pine) and mixed-conifer (YPMC) forests, including Jeffrey pine, sugar pine, white fir, lodgepole pine, incense cedar, quaking aspen, and canyon live oak. A few local and regional endemic tree species also occur, such as peninsular oak-Q. peninsularis, which fills a niche similar to black oak in southern California, and San Pedro Martír cypress-Cupressus montana. Forest understories are dominated by buckbrush, manzanita, seer's sage-Salvia divinorum, beardtongue-Penstemon spp., wildmint-Monardella spp., and needlegrass species-Stipa spp.).

Although the general environment of the SSPM is highly similar to YPMC forests of the San Jacinto Mountains or the east slopes of the SN (Dunbar-Irwin and Safford, 2016), their management histories differ markedly. Whereas, most YPMC forests in the eastern SN were extensively logged during the late $19^{\text {th }}$ and $20^{\text {th }}$ centuries, the SSPM has only experienced minor levels of timber harvesting in the lower elevations. Perhaps more importantly, fire suppression activities in the SSPM began only 30 year ago, compared with over a century of fire suppression in California (Stephens et al., 2003). Considering both lower productivity and growth rates and relatively low impacts of past forest management, forest structure and composition in the SSPM are much less altered by past management than the highly similar SN forests (Fry et al., 2014). As a result, the SSPM is considered an important living reference forest for restoration of SN dry YPMC forests (Stephens and Fulé, 2005; van Wagtendonk and Fites-Kaufman, 2006; Dunbar-Irwin and Safford, 2016). Resilience and resistance mechanisms are largely intact in these forests owing to the relative absence of timber harvest, and limited influence of fire suppression activities.

Wildfire burn severity was recently evaluated via remote sensing techniques in the SSPM for the period 1984 to 2010. Results were then compared with similar YPMC forests in the $\mathrm{SN}$, for approximately the same period (Figure 10). SSPM forests displayed a much lower fraction of high-severity burned area (3-5 vs. 30\%) than those of the SN (Rivera-Huerta et al., 2016). Historical reconstructions, modern forest reference data from SSPM, and remote sensing data all suggest that prior to EuroAmerican settlement, YPMC forests in the SN of California also experienced a primarily high frequency, low-severity fire regime, with high-severity burning seldom exceeding 5-10\% of the area (Safford and Stevens, 2017). Figure 10 shows the dramatic differences in modern burn severity between the SSPM and the $\mathrm{SN}$. Differences are driven primarily by different forest and fire management histories, with extensive logging and a century of fire suppression the SN leading to dense, layered, homogeneous, and fuels-rich forests dominated by less commerciallyvaluable fire-intolerant trees (Safford and Stevens, 2017; van Wagtendonk and Fites-Kaufman, 2006).

Past management has not only increased fire severity in YPMC forests, it has also increased susceptibility to drought and bark beetle induced mortality that has killed $>130$ million trees in the southern SN since 2015; similar mortality has not occurred in the more resilient SSPM forests (Stephens et al., 2018). Conservation of the SSPM is a high priority as it is one of the few large landscapes left in the Northern Hemisphere where forests adapted to frequent fire are still largely intact. Going forward, management that allows the continued influence of frequent fires will maintain SSPM forest in a resilient condition, and allow them to adapt gradually to changing climatic conditions. 


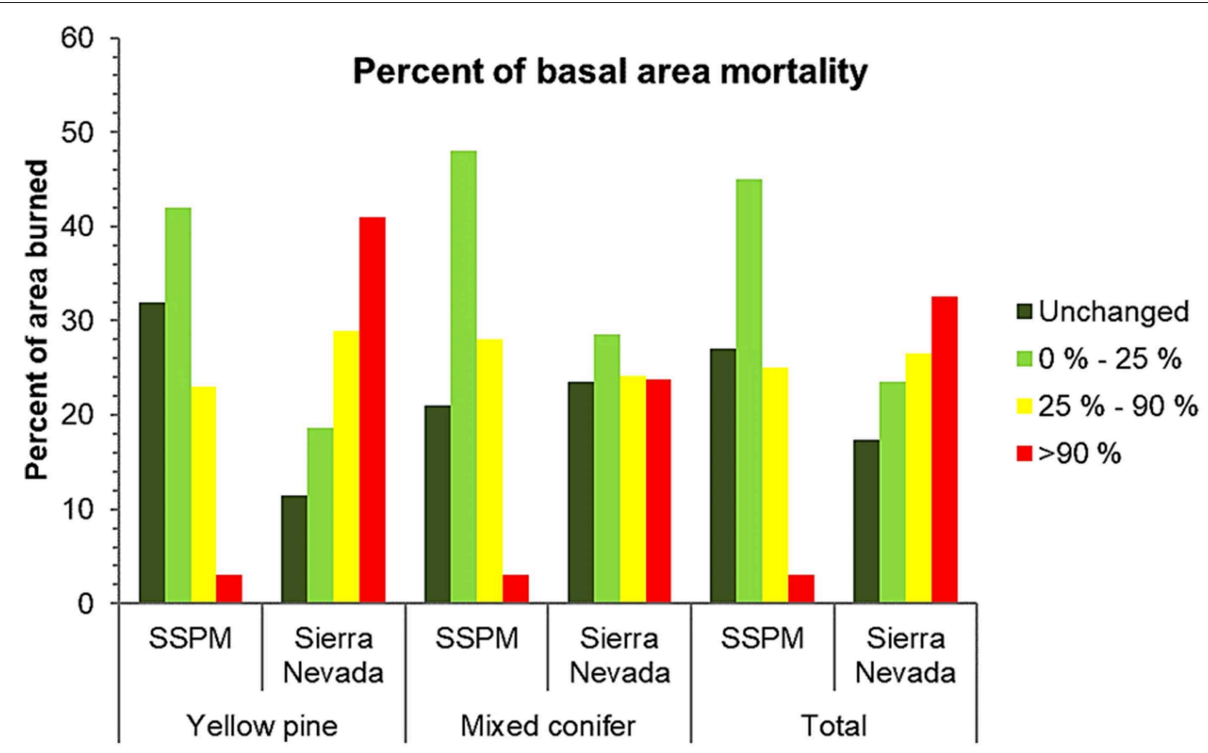

FIGURE 10 | Comparison of mean fire severity distributions in the Sierra de San Pedro Mártir (SSPM) National Park, Mexico, and the Central Sierra Nevada of California for the period 1984-2010. Sierra Nevada data from J.D. Miller, USDA Forest Service, McClellan, California. Darker green bars represent 0\% change, light green bars represent low-severity fire (0-25\% change), yellow bars represent moderate-severity fire (25-90\% change), and red bars represent high-severity fire (> $90 \%$ change, Rivera-Huerta et al., 2016). Yellow pine is another name for Jeffrey pine.

\section{SYNTHESIS}

Across western North American ecoregions, we find that a strong core of emergent properties historically conferred forest resilience and resistance to disturbances and climatic changes. We synthesize them here.

\section{Scale-Dependent Spatial Controls Drive Wildfire Behavior and Effects}

Wildfires were historically influenced by broad-, meso-, and finescale factors (Peterson et al., 1998; Moritz et al., 2011). Topdown broad-scale factors included a wide range of climatic, weather, geologic or geomorphic events. Bottom-up factors included fine-scale surface fuel loading, microsite conditions, tree density, endemic insect and disease incidence and severity, topography, and local continuity of tree canopies, ladder and understory fuels. Meso-scale factors of local landscapes included patchworks of forest and non-forest, fuel and successional conditions, productivity and topoedaphic settings. These broad, meso-, and fine-scale factors together influenced biotic and wildfire conditions. Under more extreme annual climate and fire weather conditions, top-down factors drove occurrence and effects of the largest fires. Under the most moderate climate and fire weather conditions, bottom up factors spatially controlled the sizes and effects of smaller fires. Fires in the middle range of sizes were likely driven by a tug-o-war among top-down and bottom-up factors interacting under less than extreme climate and fire weather conditions. Because forcing by top-down drivers can be so highly influential, we suggest that forest resilience and resistance have always been mutable rather than static system properties (Millar and Woolfenden, 1999). Hence, the study and characterization of historical ecology over varying climatic regions and periods is critical to understanding the components and configurations of resilient ecosystems (Swetnam et al., 1999).

\section{Cross-Connections Between Broad- and Meso-Scale Landscapes Mediate Fire Behavior and Effects}

From our survey of ecoregions, we see that historical wildfires influenced and were influenced by cross-connections between broad physiognomic patchworks of non-forest and a mix of forest successional conditions (sensu Wu and Loucks, 1995). Non-forest types had surface fuels-typically grasses, herbs, and dry or moist site shrubs-that often supported, and were supported by, moderate or high frequency fires. Historically, ignitions often spread quickly when they made contact with this non-forest patchwork, and owing to flashy fuel conditions, fires spread relatively quickly, but flame lengths and fireline intensity were fairly low. The primary fire behavior was accordingly surface rather than crownfire in the intermingled patches of dry and moist forest. Non-forest patches were not restricted to low productivity sites; some occurred in topoedaphic settings that could readily support forest. Thus, the potential extent of forest area based on climate and environmental settings alone (i.e., the carrying capacity) was seldom realized historically (Bond and Keeley, 2005). Multi-scale feedbacks with wildfire were necessary for creating and maintaining these patchworks. Characterizing the natural variability of these non-forest and preforest patchworks in each unique ecoregion and understanding the mechanisms responsible for that variability is a key to understanding and restoring broad landscape resistance to severe wildfires, and resilience in the face of climatic changes. 
Similarly, forest successional patches in drier environmental settings were open canopy with flashy surface fuels that favored surface fire spread, while those in cool-moist settings had more complexly layered fuels and instead favored mixed surface and crownfires, or predominantly crownfires. Fire controlled the successional patchwork and maintained much of the landscape in open-canopy conditions, which reduced sensitivity of trees to drought (Voelker et al., 2019). During cool-moist climatic periods of lower than average fire frequency, tree densities would increase and patches of nearby forest or woodland would expand, encroaching on and reclaiming areas of grass- and/or shrubland. However, during hot-dry climatic periods with elevated fire frequency and severity, grass, shrub, and woodland areas would again expand (e.g., see Beaty and Taylor, 2009), often in new locations, and tree densities would decline. Restoring this kind of natural spatial and temporal variation in forest successional patchworks is fundamental to restoring forest resilience (Moore et al., 1999; Keane et al., 2009).

\section{Cross-Connections Between Meso- and Fine-Scale Landscapes Influence Fire Frequency and Severity}

Across the surveyed ecoregions, we also found cross-connections and interactions whereby wildfires historically shaped and were shaped by fine-grained vegetation patterns within and among patches (Harvey et al., 2017). Fire interacted with patches of intermingled non-forest, dry, moist, and cold forests, which maintained high spatial variability in fire frequency and severity and resulted in a multi-level mosaic of seral stages and associated fuelbeds (Prichard et al., 2017). For example, frequent surface fires would spread from dry forests into adjacent moist or cold forest patches, thereby maintaining lower surface fuel loads and structures than otherwise might occur with that forest type. These spatial interactions explain the presence of open-grown lodgepole pine trees with multiple fire scars, and historical subalpine ribbon forests interspersed with wet and dry meadows (Figure 11). Historical forest successional landscapes were seldom at carrying capacity with regard to forested area or density as a consequence of disturbance mediated feedbacks operating at meso- and fine-scales.

\section{Species Traits and Adaptations Drive Patch Structure, Composition, and Response to Disturbances}

Within patches, physiological traits and adaptations of species such as serotiny, thick bark, and reproduction strategies were critical not only to species persistence, but to the maintenance of characteristic vegetation structure and composition, as well as fire severity. Medium- and large-sized ponderosa and Jeffrey pine, western larch, and Douglas-fir displayed elevated crown bases that prevented fire from climbing into the canopy, and thick bark that insulated them from most basal scorching. Shrubs resprouted from deep root systems or via seeds long buried in soils. Native grasses were fireadapted and some formed sods, which were available to reburn within a year. Bunchgrasses grew in individual tufts and
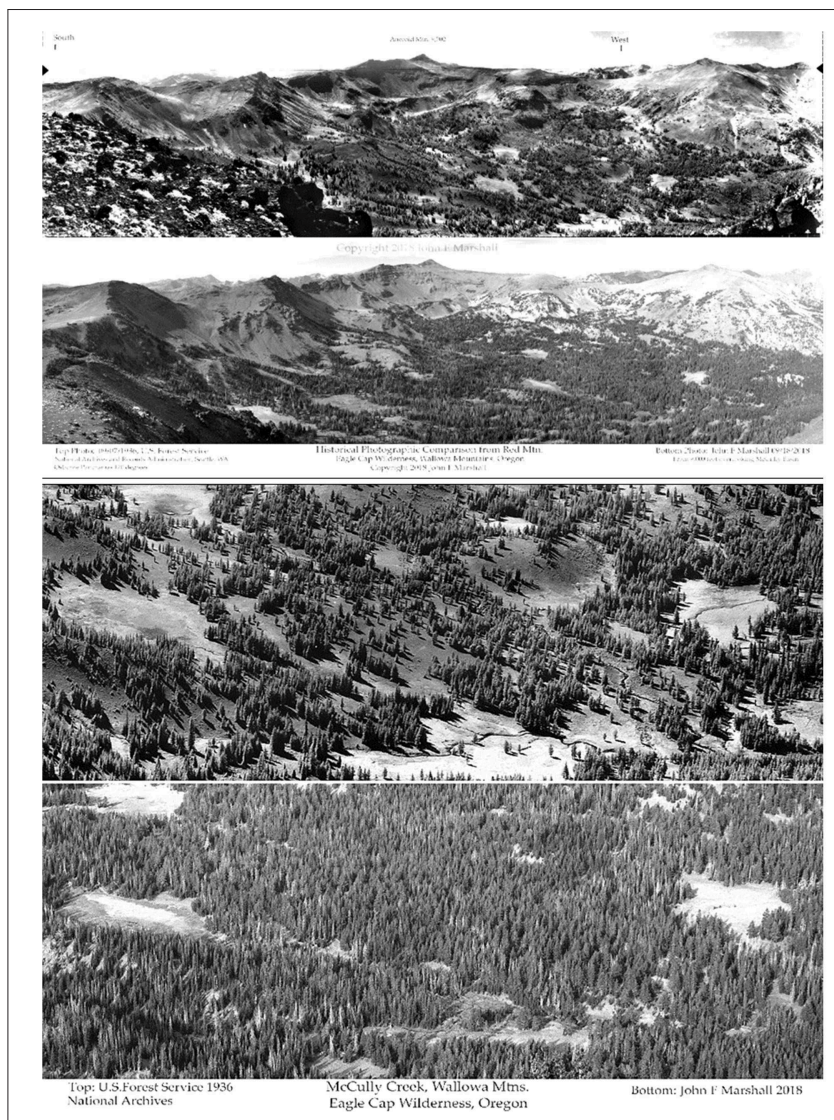

FIGURE 11 | Top pair, Panoramic $\left(120^{\circ}\right)$ comparison of high elevation $(2,400-2,700 \mathrm{~m})$ cold forests of the McCully Creek basin. Top photo is from 1936, from the William Osborne collection, looking WSW to Aneroid Mountain from the top of Red Mountain. Forests are mixed lodgepole pine, subalpine fir, and Engelmann spruce. Notice that the headwaters of this basin was historically dominated by dry and wet meadows with interspersed ribbons of forest. Bottom photo of the pair is from 2018, taken by John Marshall. Notice the infilling of forest and decline in meadow area. Bottom pair, close-up of a portion of the top photo pair. The scene is McCully Creek. Notice in the top photo, that size classes of open-grown trees are variable indicating that meadow invasion/expansion is dynamic in the interval between fires. In the bottom photo, widespread bark beetle mortality is indicated by gray lodgepole pine and spruce snags, which are absent in the top photo. Loss of meadow is conspicuous in the bottom photo.

tussocks, which provided fine-scale fuel discontinuities while also making them resistant to fire caused mortality. Patchlevel structures such as clumped and gapped tree distributions were also supported by recurrent fires (Larson and Churchill, 2012; Churchill et al., 2013; Lydersen et al., 2013). Clump and gap sizes varied predictably with species-level traits including seed dispersal distances and in-filling rates, and with patchy tree mortality driven by surface and ladder fuels (Figure 5C). Restoring more typical tree clump and gap size variation is key to restoring patch-level resistance to severe wildfires, and to adapting patches to coming climatic changes (Pawlikowski et al., 2019), particularly in dry and moist mixed conifer forests. 


\section{Climate Change Will Reduce Forest Area and Density}

Cross-connections between broad-, meso-, and fine-scale landscapes offer clues to expected warming and drying of western North America and its consequences for fire and vegetation dynamics (Keane et al., 2013; Kitzberger et al., 2017; Davis et al., 2018). Increasing moisture deficits will likely contribute to continued declines in tree vigor and forest area to levels that are even lower than occurred historically. As non-forest area grows, area burned will likely increase across flashy fuel-connected landscapes. This may have the effect of increasing fire frequency not only in dry forests, but also in some moist and cold forests, especially as they intermix with dry forests on topographically diverse landscapes. In rugged terrain, topography will continue to influence fire size and severity (Povak et al., 2018), but with continued warming, we may see an erosion of topographic controls. Increased fire frequency will reduce canopy cover and tree density while favoring plant species with traits that allow them to survive or colonize quickly following fire. These trends may ultimately increase the amount of low- and moderate-severity fire compared to what historically was associated with each forest type, thus redefining their characteristic feedbacks and the associated forest and non-forest successional conditions.

\section{CONCLUSIONS}

Resilience mechanisms are strikingly similar across a wide range of western North American environmental conditions. Resilience arises through incremental and sometimes punctuated adaptations to the prevailing climate at each level of organization. Adaptations occur at species- and community-levels via physiological and life history traits, and through physiognomic patterning at the ecoregion-level. During periods of modest climatic variation, multi-level patterns support a system that appears to be stable, while not truly stable (metastability). When fueled by extreme disturbance or climatic events, this apparent stability can mutate, changing the dominance and distribution of landscape conditions at all levels. We showed clear evidence that such changes in western North American forests have resulted from human, disturbance, and climatic influences.

Broad-scale and abrupt changes in landscape structure and organization can be difficult for native plants, animals, and human communities to withstand (Liu et al., 2007; Spies et al., 2014). Accordingly, a task for current era managers is to manage for the changes, with uncertainty clearly in mind. Promoting forest resilience or resistance to wildfires and other disturbances will require planning on an uncertain amount of unbridled and ongoing disturbance. It will necessitate being mindful and inclusive of species-level traits; characteristic patchlevel tree clump and gap distributions, tree sizes, densities, and canopy layers; meso-scale seral stage and fuelbed heterogeneity; and broad-scale forest and non-forest patchworks. Intentionally fostering ecosystems that can reside deeper in the figurative resistance basin, or that have a broad resilience basin of attraction to move around in, will lessen their vulnerability to coming climatic and wildfire regime changes. This may require preemptively adapting landscapes in areas with anticipated future water deficit, before abrupt changes occur from disturbanceor drought-related mortality events. Examples of preparing landscapes for the coming wildfire and climatic regime changes include reducing forest area, expanding woodland or grassland area, reducing canopy cover and layering, and increasing the areal extent of large trees of fire-tolerant species. In these ways, managers can also better prepare human communities for future uncertainty by reducing the likelihood of abrupt broadscale changes.

We are doubtful that purposeful and pro-active land management will succeed without active engagement of human communities that depend on these landscapes (Fischer et al., 2016). Social science research finds high levels of public support for some pro-active forest management, such as thinning and prescribed-burning on public lands with a high fire risk (Burns and Cheng, 2007; McCaffrey et al., 2013). However, it is unknown whether such support exists for mitigating other risks to forests, such as large-scale bark beetle outbreaks (Flint et al., 2009; McFarlane et al., 2012). Evidence points to public mistrust of some forest managers, and a lack of agreement about the conditions conferring large landscape vulnerability and the benefits and methods of well-timed proactive treatments (Spies et al., 2018b). Clearly more work is needed to understand the nature of interdependence among social-ecological communities and their governance before managers can reliably motivate the kind of change that results in the "greatest good for the greatest number."

Managing for resilient forest landscapes depends on scale and social values. It involves human community changes and adaptations that are concordant with the ecosystems they depend on. It entails exploiting factors and mechanisms that drive dynamics at each level to adapt landscapes, species, and human communities to climate change, while maintaining core ecosystem functions, processes, and services. Finally, it compels us to prioritize management that incorporates ongoing disturbances and anticipated effects of climatic changes, and supports dynamically shifting patchworks of forest and nonforest. Doing so could make these shifting forest conditions and wildfire regimes less disruptive to individuals and society.

\section{AUTHOR CONTRIBUTIONS}

PFH, CM, AL, NP, CA, MH, AT, PEH, SJP, VK, and DC: contributed to the conception and design of the study. PFH: wrote the first draft of the manuscript. All authors wrote sections of the manuscript and contributed to manuscript revision, read and approved the submitted version.

\section{FUNDING}

Publication of this article is funded by the Pacific Northwest Research Station, USDA Forest Service, Wenatchee, WA, USA. 


\section{REFERENCES}

Abatzoglou, J. T., and Williams, A. P. (2016). Impact of anthropogenic climate change on wildfire across western US forests. Proc. Nat. Acad. Sci. U.S.A. 113, 11770-11775. doi: 10.1073/pnas.1607171113

Addington, R. N., Aplet, G. H., Battaglia, M. A., Briggs, J. S., Brown, P. M., Cheng, A. S., et al. (2018). Principles and practices for the restoration of ponderosa pine and dry mixed-conifer forests of the Colorado Front Range. RMRS-GTR-37. Fort Collins, CO: USDA-FS, Rocky Mountain Research Station. 121p.

Agee, J. K. (1996). Fire Ecology of Pacific Northwest Forests. Washington, DC: Island Press.

Allen, C. D. (2007). Interactions across spatial scales among forest dieback, fire, and erosion in northern New Mexico landscapes. Ecosystems 10, 797-808. doi: 10.1007/s10021-007-9057-4

Allen, C. D. (2014). "Forest ecosystem reorganization underway in the Southwestern US: a preview of widespread forest changes in the Anthropocene," in Forest Conservation and Management in the Anthropocene: Proceedings RMRS-P-71:103-122 (Fort Collins, CO: USDA-FS, Rocky Mountain Research Station). Available online at: https://www.fs.fed.us/rm/pubs/rmrs_p071.pdf

Andison, D. W., and Marshall, P. L. (1999). Simulating the impact of landscape-level biodiversity guidelines: a case study. For. Chron. 75, 655-665. doi: $10.5558 / \mathrm{tfc} 75655-4$

Andison, D. W., and McCleary, K. (2014). Detecting regional differences in within-wildfire burn patterns in western boreal Canada. For. Chron. 90, 59-69. doi: 10.5558/tfc2014-011

Andrus, R. A., Harvey, B. J., Rodman, K. C., Hart, S. J., and Veblen, T. T. (2018). Moisture availability limits subalpine tree establishment. Ecology 99, 567-575. doi: $10.1002 /$ ecy. 2134

Angeler, D. G., and Allen, C. R. (2016). Quantifying resilience. J. Appl. Ecol. 53, 617-624. doi: 10.1111/1365-2664.12649

Arno, S. F., and Davis, D. H. (1981). "Fire history of western red cedar/hemlock forests in northern Idaho," in Proceedings of the Fire History Workshop (Tucson, AZ: USDA-FS).

Aukema, B. H., Carroll, A. L., Zhu, J., Raffa, K. F., Sickley, T. A., and Taylor, S. W. (2006). Landscape level analysis of mountain pine beetle in British Columbia, Canada: spatiotemporal development and spatial synchrony within the present outbreak. Ecography 29, 427-441. doi: 10.1111/j.2006.0906-7590.04445.x

Bailey, R. G. (1998). Ecoregions Map of North America: Explanatory Note. Washington DC: USDA-FS.

Baker, W. L. (2009). Fire Ecology in Rocky Mountain Landscapes. Washington, DC: Island Press.

Balch, J. K., Bradley, B. A., Abatzoglou, J. T., Nagy, R. C., Fusco, E. J., and Mahood, A. L. (2017). Human-started wildfires expand the fire niche across the United States. Proc. Nat. Acad. Sci. U.S.A. 114, 2946-2951. doi: 10.1073/pnas.1617394114

Barbour, M. G., Christensen, N. L., Morin, N. R., and Brouillet, L. (1993). "Vegetation of North America north of Mexico," in Flora of North America, Vol. 1 (Oxford: Oxford University Press), 132-153.

Battaglia, M. A., Gannon, B., Brown, P. M., Fornwalt, P. J., Cheng, A. S., and Huckaby, L. S. (2018). Changes in forest structure since 1860 in ponderosa pine dominated forests in Colorado and Wyoming Front Range, USA. For. Ecol. Mgt. 422, 147-160. doi: 10.1016/j.foreco.2018.04.010

BC Wildfire Management Branch Strategic Plan. (2012). Ministry of Forests, Lands, and Natural Resources Operations. Victoria, BC. 24 p.

Beaty, R. M., and Taylor, A. H. (2009). A 14,000 year sedimentary charcoal record of fire from the northern Sierra Nevada, Lake Tahoe Basin, California, USA. Holocene 19, 347-358. doi: 10.1177/0959683608101386

Belote, R. T., Larson, A. J., and Dietz, M. S. (2015). Tree survival scales to community-level effects following mixed-severity fire in a mixed-conifer forest. For. Ecol. Mgt. 353, 221-231. doi: 10.1016/j.foreco.2015.05.033

Bond, W. J., and Keeley, J. E. (2005). Fire as a global 'herbivore': the ecology and evolution of flammable ecosystems. Trends Ecol. Evol. 20, 387-394. doi: 10.1016/j.tree.2005.04.025

Boulanger, Y., Gauthier, S., and Burton, P. J. (2014). A refinement of models projecting future Canadian fire regimes using homogeneous fire regime zones. Can. J. For. Res. 44, 365-376. doi: 10.1139/cjfr-2013-0372

Boyd, R. (ed.) (1999). Indians, Fire and the Land. Corvallis, OR: Oregon State University Press.
Briles, C. E., Whitlock, C., Bartlein, P. J., and Higuera, P. (2008). Regional and local controls on postglacial vegetation and fire in the Siskiyou Mountains, northern California, USA. Palaeogeog. Palaeoclim. Palaeoecol. 265, 159-169. doi: $10.1016 /$ j.palaeo.2008.05.007

Brown, P. M., Battaglia, M. A., Fornwalt, P. J., Gannon, B., Huckaby, L. S., Julian, C., et al. (2015). Historical (1860) forest structure in ponderosa pine forests of the northern Front Range, Colorado. Can. J. For. Res. 45, 1462-1473. doi: 10.1139/cjfr-2014-0387

Brown, P. M., Kaufmann, M. R., and Shepperd, W. D. (1999). Long-term, landscape patterns of past fire events in a montane ponderosa pine forest of central Colorado. Land. Ecol. 14, 513-532. doi: 10.1023/A:1008137 005355

Bullock, H. S. (1999). La vegetación del noroeste de Baja California en el contexto de la inestabilidad ambiental. Revista Chilena Hist. Nat. 72, 501-516.

Burns, M., and Cheng, A. S. (2007). Framing the need for active management for wildfire mitigation and forest restoration. Soc. Nat. Res. 20, 245-259. doi: $10.1080 / 08941920601117348$

Burton, P. J., and Boulanger, Y. (2018). Characterizing combined fire and insect outbreak disturbance regimes in British Columbia, Canada. Landscape Ecol. 33, 1997-2011. doi: 10.1007/s10980-018-0710-4

Calder, W. J., Parker, D., Stopka, C. J., Jiménez-Moreno, G., and Shuman, B. N. (2015). Medieval warming initiated exceptionally large wildfire outbreaks in the Rocky Mountains. Proc. Nat. Acad. Sci. U.S.A. 112, 13261-13266. doi: 10.1073/pnas.1500796112

Calder, W. J., and Shuman, B. (2017). Extensive wildfires, climate change, and an abrupt state change in subalpine ribbon forests, Colorado. Ecology 98, 2585-2600. doi: 10.1002/ecy.1959

Calkin, D. E., Cohen, J. D., Finney, M. A., and Thompson, M. P. (2014). How risk management can prevent future wildfire disasters in the wildland-urban interface. Proc. Nat. Acad. Sci. U.S.A. 111, 746-751. doi: $10.1073 /$ pnas.1315088111

Cansler, C. A., and McKenzie, D. (2014). Climate, fire size, and biophysical setting control fire severity and spatial pattern in the northern Cascade Range, USA. Ecol. Appl. 24, 1037-1056. doi: 10.1890/13-1077.1

Carroll, A. L., Taylor, S. W., Régnière, J., and Safranyik, L. (2004). "Effects of climate change on range expansion by the mountain pine beetle in British Columbia," in Mountain Pine Beetle Symposium: Challenges and Solutions. Victoria, BC: Natural Resources Canada, Canadian Forest Service, Pacific Forestry Centre. Information Report BC-X-399:223-232.

Chapman, T. B., Veblen, T. T., and Schoennagel, T. (2012). Spatiotemporal patterns of mountain pine beetle activity in the southern Rocky Mountains. Ecology 93, 2175-2185. doi: 10.1890/11-1055.1

Chavardès, R. D., and Daniels, L. D. (2016). Altered mixed-severity fire regime has homogenized montane forests of Jasper National Park. Int. J. Wildl. Fire 25, 433-444. doi: 10.1071/WF15048

Christianson, A. (2015). Social science research on indigenous wildfire management in the $21^{\text {st }}$ century and future research needs. Int. J. Wildl. Fire 24, 190-200. doi: 10.1071/WF13048

Churchill, D. J., Larson, A. J., Dahlgreen, M. C., Franklin, J. F., Hessburg, P. F., and Lutz, J. A. (2013). Restoring forest resilience: from reference spatial patterns to silvicultural prescriptions and monitoring. For. Ecol. Mgt. 291, 442-457. doi: 10.1016/j.foreco.2012.11.007

Clyatt, K. A., Crotteau, J. S., Schaedel, M. S., Wiggins, H. L., Kelley, H., Churchill, D. J., et al. (2016). Historical spatial patterns and contemporary tree mortality in dry mixed-conifer forests. For. Ecol. Mgt. 361, 23-37. doi: 10.1016/j.foreco.2015.10.049

Collins, B. M., Das, A. J., Battles, J. J., Fry, D. L., Krasnow, K. D., and Stephens, S. L. (2014). Beyond reducing fire hazard: fuel treatment impacts on overstory tree survival. Ecol. Appl. 24, 1879-1886. doi: 10.1890/14-0971.1

Collins, B. M., Lydersen, J. M., Everett, R. G., Fry, D. L., and Stephens, S. L. (2015). Novel characterization of landscape-level variability in historical vegetation structure. Ecol. Appl. 25, 1167-1174. doi: 10.1890/14-1797.1

Coop, J. D., Parks, S. A., McClernan, S. R., and Holsinger, L. M. (2016). Influences of prior wildfires on vegetation response to subsequent fire in a reburned Southwestern landscape. Ecol. Appl. 26, 346-354. doi: 10.1890/15-0775

Coppoletta, M., Merriam, K. E., and Collins, B. M. (2016). Post-fire vegetation and fuel development influences fire severity patterns in reburns. Ecol. Appl. 26, 686-699. doi: 10.1890/15-0225 
Courtney Mustafi, C. J., and Pisaric, M. P. J. (2014). Holocene climate-firvegetation interactions at a subalpine watershed in southeastern British Columbia, Canada. Quat. Res. 81, 228-239. doi: 10.1016/j.yqres.2013.12.002

Covington, W. W., and Moore, M. M. (1994). Postsettlement changes in natural fire regimes and forest structure: ecological restoration of old-growth ponderosa pine forests. J. Sustain. Forest. 2, 153-181.

Daly, C., Halbleib, M., Smith, J. I., Gibson, W. P., Doggett, M. K., Taylor, G. H., et al. (2008). Physiographically sensitive mapping of climatological temperature and precipitation across the conterminous United States. Int. J. Clim. 28, 2031-2064. doi: 10.1002/joc. 1688

Daniels, L. D., and Gray, R. W. (2006). Disturbance regimes in coastal British Columbia. BC J. Ecosys. Mgt. 7, 44-56.

Davis, K. T., Dobrowski, S. Z., Higuera, P. E., Holden, Z. A., Veblen, T. T., Rother, M. T., et al. (2019). Wildfires and climate change push low-elevation forests across a critical climate threshold for tree regeneration. Proc. Nat. Acad. Sci. U.S.A. 116, 6193-6198. doi: 10.1073/pnas.1815107116

Davis, K. T., Higuera, P. E., and Sala, A. (2018). Anticipating fire-mediated impacts of climate change using a demographic framework. Funct. Ecol. 32, 1729-1745. doi: $10.1111 / 1365-2435.13132$

Dolanc, C. R., Thorne, J. H., and Safford, H. D. (2013). Widespread shifts in the demographic structure of subalpine forests in the Sierra Nevada, California, 1934 to 2007. Glob. Ecol. Biogeog. 22, 264-276. doi: 10.1111/j.1466-8238.2011.00748.x

Dunbar-Irwin, M., and Safford, H. D. (2016). Climatic and structural comparison of yellow pine and mixed-conifer forests in northern Baja California (Mexico) and the eastern Sierra Nevada (California, USA). For. Ecol. Mgt. 363, 252-266. doi: 10.1016/j.foreco.2015.12.039

Dunnette, P. V., Higuera, P. E., McLauchlan, K. K., Derr, K. M., Briles, C. E., and Keefe, M. H. (2014). Biogeochemical impacts of wildfires over four millennia in a Rocky Mountain subalpine watershed. New Phytol. 203, 900-912. doi: $10.1111 / \mathrm{nph} .12828$

Estes, B. L., Knapp, E. E., Skinner, C. N., Miller, J. D., and Preisler, H. K. (2017). Factors influencing fire severity under moderate burning conditions in the Klamath Mountains, northern California, USA. Ecosphere 8:e01794. doi: $10.1002 /$ ecs2.1794

Fernandes, P. M., and Botelho, H. S. (2003). A review of prescribed burning effectiveness in fire hazard reduction. Int. J. Wildl. Fire 12, 117-128. doi: 10.1071/WF02042

Fischer, A. P., Spies, T. A., Steelman, T. A., Moseley, C., Johnson, B. R., Bailey, J. D., et al. (2016). Wildfire risk as a socioecological pathology. Front. Ecol. Env. 14, 276-284. doi: 10.1002/fee.1283

Flint, C. G., McFarlane, B., and Müller, M. (2009). Human dimensions of forest disturbance by insects: an international synthesis. Env. Mgt. 43, 1174-1186. doi: 10.1007/s00267-008-9193-4

Fry, D. L., Stephens, S. L., Collins, B. M., North, M. P., Franco-Vizcaíno, E., and Gill, S. J. (2014). Contrasting spatial patterns in active-fire and fire-suppressed Mediterranean climate old-growth mixed-conifer forests. PLoS ONE 9:e88985. doi: 10.1371/journal.pone.0088985

Fry, D. L., Stevens, J. T., Potter, A. T., Collins, B. M., and Stephens, S. L. (2018). Surface fuel accumulation and decomposition in old-growth pine-mixed conifer forests, northwestern Mexico. Fire Ecol. 14, 1-6. doi: 10.1186/s42408-018-0017-5

Grabinski, Z. S., Sherriff, R. L., and Kane, J. M. (2017). Controls of reburn severity vary with fire interval in the Klamath Mountains, California, USA. Ecosphere 8:e02012. doi: 10.1002/ecs2.2012

Greene, G. A., and Daniels, L. D. (2017). Spatial interpolation and mean fire interval analyses quantify historical mixed-severity fire regimes. Int. J. Wildland Fire 26:138-147. doi: 10.1071/WF16084

Gregory, R., Failing, L., Harstone, M., Long, G., McDaniels, T., and Ohlson, D. (2012). Structured Decision Making: A Practical Guide to Environmental Management Choices. Chichester, UK: John Wiley and Sons. doi: 10.1002/9781444398557

Hagmann, R. K., Franklin, J. F., and Johnson, K. N. (2014). Historical conditions in mixed-conifer forests on the eastern slopes of the northern Oregon Cascade Range, USA. For. Ecol. Mgt. 330, 158-170. doi: 10.1016/j.foreco.2014.0 6.044

Hagmann, R. K., Merschel, A. G., and Reilly, M. J. (2019). Historical patterns of fire severity and forest structure and composition in a landscape structured by frequent large fires: pumice Plateau ecoregion, Oregon, USA. Land. Ecol. 34, 551-568. doi: 10.1007/s10980-019-00791-1

Hamrick, J. L. (2004). Response of forest trees to global environmental changes. For. Ecol. Mgt. 197, 323-335. doi: 10.1016/j.foreco.2004.05.023

Hart, S. J., Veblen, T. T., Mietkiewicz, N., and Kulakowski, D. (2015). Negative feedbacks on bark beetle outbreaks: Widespread and severe spruce beetle infestation restricts subsequent infestation. PLOS ONE 10:e0127975. doi: 10.1371/journal.pone.0127975

Harvey, J. E., Smith, D. J., and Veblen, T. T. (2017). Mixed-severity fire history at a forest-grassland ecotone in west central British Columbia, Canada. Ecol. Appl. 27, 1746-1760. doi: 10.1002/eap.1563

Hessburg, P. F., and Agee, J. K. (2003). An environmental narrative of inland northwest United States forests, 1800-2000. For. Ecol. Mgt. 178, 23-59. doi: 10.1016/S0378-1127(03)00052-5

Hessburg, P. F., Agee, J. K., and Franklin, J. F. (2005). Dry forests and wildland fires of the inland Northwest USA: Contrasting the landscape ecology of the pre-settlement and modern eras. For. Ecol. Mgt. 211, 117-139. doi: 10.1016/j.foreco.2005.02.016

Hessburg, P. F., Churchill, D. J., Larson, A. J., Haugo, R. D., Miller, C., Spies, T. A., et al. (2015). Restoring fire-prone Inland Pacific landscapes: seven core principles. Land. Ecol. 30, 1805-1835. doi: 10.1007/s10980-015-0218-0

Hessburg, P. F., Salter, R. B., and James, K. M. (2007). Re-examining fire severity relations in pre-management era mixed-conifer forests: inferences from landscape patterns of forest structure. Land. Ecol. 22, 5-24. doi: 10.1007/s10980-007-9098-2

Hessburg, P. F., Smith, B. G., Salter, R. B., Ottmar, R. D., and Alvarado, E. (2000). Recent changes (1930s-1990s) in spatial patterns of interior northwest forests, USA. For. Ecol. Mgt. 136, 53-83. doi: 10.1016/S0378-1127(99)00263-7

Hessburg, P. F., Spies, T. A., Perry, D. A., Skinner, C. N., Taylor, A. H., Brown, P. M., et al. (2016). Tamm Review: Management of mixed-severity fire regime forests in Oregon, Washington, and Northern California. For. Ecol. Mgt. 366, 221-250. doi: 10.1016/j.foreco.2016.01.034

Hessl, A. E., McKenzie, D., and Schellhaas, R. (2004). Drought and Pacific Decadal Oscillation linked to fire occurrence in the inland Pacific Northwest. Ecol. Appl. 14, 425-442. doi: 10.1890/03-5019

Heyerdahl, E. K., McKenzie, D., Daniels, L. D., Hessl, A. E., Littell, J. S., and Mantua, N. J. (2008a). Climate drivers of regionally synchronous fires in the inland Northwest (1651-1900). Int. J. Wildl. Fire 17, 40-49. doi: 10.1071/WF07024

Heyerdahl, E. K., Morgan, P., and Riser J. P. (2008b). Multi-season climate synchronized historical fires in dry forests (1650-1900), northern Rockies, USA Ecol. 89, 705-716. doi: 10.1890/06-2047.1

Higuera, P. E., Abatzoglou, J. T., Littell, J. S., and Morgan, P. (2015). The changing strength and nature of fire-climate relationships in the Northern Rocky Mountains, U.S.A., 1902-2008. PLoS ONE 10:e0127563. doi: 10.1371/journal.pone.0127563

Higuera, P. E., Briles, C. E., and Whitlock, C. (2014). Fire-regime complacency and sensitivity to centennial-through millennial-scale climate change in Rocky Mountain subalpine forests, Colorado, USA. J. Ecol. 102, 1429-1441. doi: 10.1111/1365-2745.12296

Holden, Z. A., Swanson, A., Luce, C. H., Jolly, W. M., Maneta, M., Oyler, J. W., et al. (2018). Decreasing fire season precipitation increased recent western US forest wildfire activity. Proc. Nat. Acad. Sci. U.S.A. 115, 8349-8357. doi: $10.1073 /$ pnas. 1802316115

Holling, C. S. (1973). Resilience and stability of ecological systems. Ann. Rev. Ecol. Syst. 4, 1-23. doi: 10.1146/annurev.es.04.110173.000245

Holling, C. S. (1986). “The resilience of terrestrial ecosystems: local surprise and global change," in Sustainable Development of the Biosphere, eds W. C. Clark and R. E. Munn (Cambridge University Press), 292-317.

Huckaby, L. S., Kaufmann, M. R., Stoker, J. M., and Fornwalt, P. J. (2001). Landscape Patterns of Montane Forest Age Structure Relative to Fire History at Cheesman Lake in the Colorado Front Range. Fort Collins, CO: USDA-FS Proc. RMRS-P-22:19-27, Rocky Mountain Research Station.

Hurteau, M., and North, M. (2009). Fuel treatment effects on tree-based forest carbon storage and emissions under modeled wildfire scenarios. Front. Ecol. Env. 7, 409-414. doi: 10.1890/080049

Hurteau, M. D., Bradford, J. B., Fulé, P. Z., Taylor, A. H., and Martin, K. L. (2014). Climate change, fire management, and ecological services in the 
southwestern US. For. Ecol. Mgt. 327, 280-289. doi: 10.1016/j.foreco.2013. 08.007

Jolly, W. M., Cochrane, M. A., Freeborn, P. H., Holden, Z. A., Brown, T. J., Williamson, G. J., et al. (2015). Climate-induced variations in global wildfire danger from 1979 to 2013. Nat. Commun. 6:7537. doi: 10.1038/ncomms8537

Keane, R. E., Cary, G. J., Flannigan, M. D., Parsons, R. A., Davies, I. D., King, K. J., et al. (2013). Exploring the role of fire, succession, climate, and weather on landscape dynamics using comparative modeling. Ecol. Mod. 266, 172-186. doi: 10.1016/j.ecolmodel.2013.06.020

Keane, R. E., Hessburg, P. F., Landres, P. B., and Swanson, F. J. (2009). The use of historical range and variability (HRV) in landscape management. For. Ecol. Mgt. 258, 1025-1037. doi: 10.1016/j.foreco.2009.05.035

Keane, R. E., Ryan, K. C., Veblen, T. T., Allen, C. D., Logan, J., and Hawkes, B. (2002). The Cascading Effects of Fire Exclusion in Rocky Mountain Ecosystems: A Literature Review. Gen. Tech. Rep. RMRS-GTR-91. Fort Collins, CO: USDA-FS, Rocky Mountain Research Station. 24 p. doi: 10.2737/RMRS-GTR-91

Kemp, K. B., Higuera, P. E., and Morgan, P. (2016). Fire legacies impact conifer regeneration across environmental gradients in the U.S. Northern Rockies. Land. Ecol. 31, 619-636. doi: 10.1007/s10980-015-0268-3

Kitzberger, T., Brown, P. M., Heyerdahl, E. K., Swetnam, T. W., and Veblen, T. T. (2007). Contingent Pacific-Atlantic ocean influence on multi-century wildfire synchrony over western North America. Proc. Nat. Acad. Sci. U.S.A. 104, 543-548. doi: 10.1073/pnas.0606078104

Kitzberger, T., Falk, D. A., Westerling, A. L., and Swetnam, T. W. (2017). Direct and indirect climate controls predict heterogeneous early-mid 21st century wildfire burned area across western and boreal North America. PLOS ONE 12:e0188486. doi: 10.1371 /journal.pone. 0188486

Krawchuk, M. A., Haire, S. L., Coop, J., Parisien, M.-A., Whitman, E., Chong, G., et al. (2016). Topographic and fire weather controls of fire refugia in forested ecosystems of northwestern North America. Ecosphere 7:e01632. doi: $10.1002 /$ ecs 2.1632

Krawchuk, M. A., and Moritz, M. A. (2011). Constraints on global fire activity vary across a resource gradient. Ecology 92, 121-132. doi: 10.1890/09-1843.1

Krawchuk, M. A., Moritz, M. A., Parisien, M. A., Van Dorn, J., and Hayhoe, K. (2009). Global pyrogeography: the current and future distribution of wildfire. PLoS ONE 4:e5102. doi: 10.1371/journal.pone.0005102

Landres, P. B., Morgan, P., and Swanson, F. J. (1999). Overview of the use of natural variability concepts in managing ecological systems. Ecol. Appl. 9, 1179-1188. doi: 10.1890/1051-0761(1999)009[1179:OOTUON]2.0.CO;2

Larson, A. J., Belote, R. T., Cansler, C. A., Parks, S. A., and Dietz, M. S. (2013). Latent resilience in ponderosa pine forest: effects of resumed frequent fire. Ecol. Appl. 23, 1243-1249. doi: 10.1890/13-0066.1

Larson, A. J., and Churchill, D. J. (2012). Tree spatial patterns in fire-frequent forests of western North America, including mechanisms of pattern formation and implications for designing fuel reduction and restoration treatments. For. Ecol. Mgt. 267, 74-92. doi: 10.1016/j.foreco.2011.11.038

Lauvaux, C. A., Skinner, C. N., and Taylor, A. H. (2016). High-severity fire and mixed-conifer forest-chaparral dynamics in the southern Cascade Range, USA. For. Ecol. Mgt. 363, 74-85. doi: 10.1016/j.foreco.2015.12.016

Lewis, M., Christianson, A., and Spinks, M. (2018). Return to flame: Reasons for burning in Lytton First Nation, British Columbia. J. For. 116, 143-150. doi: $10.1093 /$ jofore/fvx 007

Littell, J. S., McKenzie, D., Peterson, D. L., and Westerling, A. L. (2009). Climate and wildfire area burned in western US ecoprovinces, 1916-2003. Ecol. Appl. 19, 1003-1021. doi: 10.1890/07-1183.1

Littell, J. S., McKenzie, D., Wan, H. Y., and Cushman, S. A. (2018). Climate change and future wildfire in the western United States: an ecological approach to nonstationarity. Earths Fut. 6, 1097-1111. doi: 10.1029/2018EF000878

Liu, J., Dietz, T., Carpenter, S. R., Alberti, M., Folke, C., Moran, E., et al. (2007). Complexity of coupled human and natural systems. Science 317, 1513-1516. doi: $10.1126 /$ science. 1144004

Logan, J. A., MacFarlane, W. W., and Willcox, L. (2010). Whitebark pine vulnerability to climate-driven mountain pine beetle disturbance in the Greater Yellowstone Ecosystem. Ecol. Appl. 20, 895-902. doi: 10.1890/09-0655.1

Lundquist, J. D., Dickerson-Lange, S. E., Lutz, J. A., and Cristea, N. C. (2013). Lower forest density enhances snow retention in regions with warmer winters: a global framework developed from plot-scale observations and modeling. Water Resour. Res. 49, 6356-6370. doi: 10.1002/wrcr.20504
Lydersen, J., and North, M. (2012). Topographic variation in active-fire forest structure under current climate conditions. Ecosystem 15, 1134-1146. doi: 10.1007/s10021-012-9573-8

Lydersen, J. M., and Collins, B. M. (2018). Change in vegetation patterns over a large forested landscape based on historical and contemporary aerial photography. Ecosystem 18, 1-16. doi: 10.1007/s10021-018-0225-5

Lydersen, J. M., North, M. P., Knapp, E. E., and Collins, B. M. (2013). Quantifying spatial patterns of tree groups and gaps in mixed-conifer forests: reference conditions and long-term changes following fire suppression and logging. For. Ecol. Mgt. 304, 370-382. doi: 10.1016/j.foreco.2013.05.023

Maloy, O. C. (1997). White pine blister rust control in North America: a case history. Ann. Rev. Phytopath. 35, 87-109. doi: 10.1146/annurev.phyto.35.1.87

Marcoux, H. M., Daniels, L. D., Gergel, S. E., Da Silva, E., Gedalof, Z., and Hessburg, P. F. (2015). Differentiating mixed-and high-severity fire regimes in mixed-conifer forests of the Canadian Cordillera. For. Ecol. Mgt. 341, 45-58. doi: 10.1016/j.foreco.2014.12.027

Marcoux, H. M., Gergel, S. E., and Daniels, L. D. (2013). Mixed-severity fire regimes: how well are they represented by existing fire-regime classification systems? Can. J. For. Res. 43, 658-668. doi: 10.1139/cjfr-2012-0449

Margolis, E. Q., Swetnam, T. W., and Allen, C. D. (2011). Historical stand-replacing fire in upper montane forests of the Madrean Sky Islands and Mogollon Plateau, southwestern USA. Fire Ecol. 7, 88-107. doi: 10.4996/fireecology. 0703088

Marlon, J. R., Bartlein, P. J., Gavin, D. G., Long, C. J., Anderson, R. S., Briles, C. E., et al. (2012). Long-term perspective on wildfires in the western USA. Proc. Nat. Acad. Sci. U.S.A. 109:E535-E543. doi: 10.1073/pnas.1112839109

McCaffrey, S., Toman, E., Stidham, M., and Shindler, B. (2013). Social science research related to wildfire management: an overview of recent findings and future research needs. Int. J. Wildl. Fire 22, 15-24. doi: 10.1071/WF 11115

McFarlane, B. L., Parkins, J. R., and Watson, D. O. (2012). Risk, knowledge, and trust in managing forest insect disturbance. Can. J. For. Res. 42, 710-719. doi: $10.1139 / \mathrm{x} 2012-030$

McKenzie, D., and Littell, J. S. (2017). Climate change and the eco-hydrology of fire: will area burned increase in a warming western USA? Ecol. Appl. 27, 26-36. doi: 10.1002/eap.1420

Meidinger, D., and Pojar, J. (1991). Ecosystems of British Columbia. Victoria, BC: BC Ministry of Forests. $330 \mathrm{p}$.

Meigs, P. (1935). The Dominican Missions Frontier of Lower California. Berkeley, CA: University of California Publications in Geography.

Michael, B., Pavlick, B., Drysdale, F., and Lindstrom, S. (1993). California's Changing landscapes, Diversity and Conservation of California Vegetation. Sacramento, CA: Cal. Native Plant Soc.

Millar, C. I., and Rundel, P. W. (2016). "Subalpine forest," in Ecosystems of California (Oakland, CA: University of California Press), 679-612.

Millar, C. I., and Woolfenden, W. B. (1999). The role of climate change in interpreting historical variability. Ecol. Appl. 9, 1207-1216. doi: 10.1890/10510761(1999)009[1207:TROCCI]2.0.CO;2

Miller, A. D., Thompson, J. R., Tepley, A. J., and Anderson-Teixeira, K. J. (2018). Alternative stable equilibria and critical thresholds created by fire regimes and plant responses in a fire-prone community. Ecogr. 41, 1-12. doi: 10.1111/ecog.03491

Minnich, R. A., Barbour, M. G., Burk, J. H., and Sosa-Ramirez, J. (2000). California Mixed-Conifer forests under unmanaged fire regimes in the Sierra San Pedro Mártir, Baja California, Mexico. J. Biogeogr. 27, 105-129. doi: 10.1046/j.1365-2699.2000.00368.x

Moore, M. M., Wallace Covington, W., and Fulé, P. Z. (1999). Reference conditions and ecological restoration: a southwestern ponderosa pine perspective. Ecol. Appl. 9, 1266-1277. doi: 10.1890/1051-0761(1999)009[1266:RCAERA]2. $0 . \mathrm{CO} ; 2$

Morgan, P., Heyerdahl, E. K., and Gibson, C. E. (2008). Multi-season climate synchronized forest fires throughout the $20^{\text {th }}$ century, Northern Rockies, USA. Ecology 89, 717-728. doi: 10.1890/06-2049.1

Moritz, M. A., Hessburg, P. F., and Povak, N. A. (2011). "Native fire regimes and landscape resilience," in The Landscape Ecology of Fire (Dordrecht: Springer), 51-86. doi: 10.1007/978-94-007-0301-8_3

Naficy, C., Sala, A., Keeling, E. G., Graham, J., and DeLuca, T. H. (2010). Interactive effects of historical logging and fire exclusion on ponderosa 
pine forest structure in the northern Rockies. Ecol. Appl. 20, 1851-1864. doi: 10.1890/09-0217.1

New, M., Hulme, M., and Jones, P. (1999). Representing twentieth-century spacetime climate variability. Part I: development of a 1961-90 mean monthly terrestrial climatology. J. Clim. 12, 829-856.

North, M., Collins, B., Safford, H., and Stephenson, N. L. (2016). "Montane forests," in Ecosystems of California (Oakland, CA: University of California Press), 553-578.

North, M. P., Collins, B. M., and Stephens, S. L. (2012). Using fire to increase the scale, benefits and future maintenance of fuels treatments. J. For. 110, 392-401. doi: 10.5849/jof.12-021

North, M. P., Stephens, S. L., Collins, B. M., Agee, J. K., Aplet, G., Franklin, J. F., et al. (2015). Reform forest fire management. Science 349, 1280-1281. doi: $10.1126 /$ science.aab2356

O’Connor, C. D., Falk, D. A., Lynch, A. M., Swetnam, T. W., and Wilcox, C. P. (2017). Disturbance and productivity interactions mediate stability of forest composition and structure. Ecol. Appl. 27, 900-915. doi: 10.1002/ eap. 1492

Olson, D. M., and Dinerstein, E. (2002). “The global 200: priority ecoregions for global conservation," in Annals of the Missouri Botanical Garden, 199-224.

Ouzts, J., Kolb, T., Huffman, D., and Meador, A. S. (2015). Post-fire ponderosa pine regeneration with and without planting in Arizona and New Mexico. Forest Ecol. Manage. 354, 281-290. doi: 10.1016/j.foreco.2015.06.001

Parks, S. A., Dobrowski, S. Z., Shaw, J. D., and Miller, C. (2019). Living on the edge: trailing edge forests at risk of fire-facilitated conversion to non-forest. Ecosphere 10:e02651. doi: 10.1002/ecs2.2651

Parks, S. A., Holsinger, L. M., Miller, C., and Nelson, C. R. (2015). Wildland fire as a self-regulating mechanism: The role of previous burns and weather in limiting fire progression. Ecol. Appl. 25, 1478-92. doi: 10.1890/14-1430.1

Parks, S. A., Holsinger, L. M., Miller, C., and Parisien, M.-A. (2018). Analog-based fire regime and vegetation shifts in mountainous regions of the western US. Ecography 41, 910-921. doi: 10.1111/ecog.03378

Parks, S. A., Miller, C., Holsinger, L. M., Baggett, L. S., and Bird, B. J. (2016). Wildland fire limits subsequent fire occurrence. Int. J. Wildl. Fire 25, 182-190. doi: 10.1071/WF15107

Parks, S. A., Miller, C., Nelson, C. R., and Holden, Z. A. (2014). Previous fires moderate burn severity of subsequent wildland fires in two large western US wilderness areas. Ecosystem 17, 29-42. doi: 10.1007/s10021-013-9704-x

Pawlikowski, N. C., Coppoletta, M., Knapp, E., and Taylor, A. H. (2019). Spatial dynamics of tree group and gap structure in an old-growth ponderosa pineCalifornia black oak forest burned by repeated wildfires. For. Ecol. Mgt. 434, 289-302. doi: 10.1016/j.foreco.2018.12.016

Pelz, K. A., Rhoades, C. C., Hubbard, R. M., Battaglia, M. A., and Smith, F. W. (2015). Species composition influences management outcomes following mountain pine beetle in lodgepole pine-dominated forests. For. Ecol. Mgt. 336, 11-20. doi: 10.1016/j.foreco.2014.09.034

Peterson, G., Allen, C. R., and Holling, C. S. (1998). Ecological resilience, biodiversity, and scale. Ecosystem 1, 6-18. doi: 10.1007/s100219900002

Povak, N. A., Hessburg, P. F., and Salter, R. B. (2018). Evidence for scaledependent topographic controls on wildfire spread. Ecosphere 9:e02443. doi: $10.1002 /$ ecs 2.2443

Prichard, S. J., Stevens-Rumann, C. S., and Hessburg, P. F. (2017). Tamm review: shifting global fire regimes: Lessons from reburns and research needs. For. Ecol. Mgt. 396, 217-233. doi: 10.1016/j.foreco.2017.03.035

Province of British Columbia (2018). Mountain Pine Beetle in B.C. Available online at: https://www2.gov.bc.ca/gov/content/industry/forestry/managingour-forest-resources/forest-health/forest-pests/bark-beetles/mountain-pinebeetle (accessed October 5, 2018).

Raffa, K. F., Aukema, B. H., Bentz, B. J., Carroll, A. L., Hicke, J. A., Turner, M. G., et al. (2008). Cross-scale drivers of natural disturbances prone to anthropogenic amplification: the dynamics of bark beetle eruptions. Bio Sci. 58, 501-519. doi: 10.1641/B580607

Reilly, M. J., Dunn, C. J., Meigs, G. W., Spies, T. A., Kennedy, R. E., Bailey, J. D., et al. (2017). Contemporary patterns of fire extent and severity in forests of the Pacific Northwest, USA (1985-2010). Ecosphere 8:e01695. doi: $10.1002 /$ ecs2.1695

Rivera-Huerta, H., Safford, H. D., and Miller, J. D. (2016). Patterns and trends in burned area and fire severity from 1984 to 2010 in the Sierra de San Pedro Mártir, Baja California, Mexico. Fire Ecol. 12, 52-72. doi: 10.4996/fireecology.1201052

Rollins, M. G. (2009). LANDFIRE: a nationally consistent vegetation, wildland fire, and fuel assessment. Int. J. Wildl. Fire 18, 235-249. doi: 10.1071/WF08088

Safford, H. D., and Stevens, J. T. (2017). Natural Range of Variation (NRV) for Yellow Pine and Mixed-Conifer Forests in the Sierra Nevada, Southern Cascades, and Modoc and Inyo National Forests, California, USA. Albany, CA: Gen. Tech. Rep. PSW-GTR-256, USDA-FS, Pacific Southwest Research Station.

Scheffer, M., Carpenter, S., Foley, J. A., Folke, C., and Walker, B. (2001). Catastrophic shifts in ecosystems. Nature 413, 591-596. doi: 10.1038/35098000

Schoennagel, T., Veblen, T. T., and Romme, W. H. (2004). The interaction of fire, fuels, and climate across Rocky Mountain forests. Bio Sci. 54, 661-676. doi: 10. 1641/0006-3568(2004)054[0661:TIOFFA]2.0.CO;2

Schoennagel, T., Veblen, T. T., Romme, W. H., Sibold, J. S., and Cook, E. R. (2005). ENSO and PDO variability affect drought-induced fire occurrence in Rocky Mountain subalpine forests. Ecol. Appl. 15, 2000-2014. doi: 10.1890/04-1579

Serra-Diaz, J. M., Maxwell, C., Lucash, M. S., Scheller, R. M., Laflower, D. M., Miller, A. D., et al. (2018). Disequilibrium of fire-prone forests sets the stage for a rapid decline in conifer dominance during the 21st century. Sci. Rep. 8:6749. doi: 10.1038/s41598-018-24642-2

Sherriff, R. L., Platt, R. V., Veblen, T. T., Schoennagel, T. L., and Gartner, M. H. (2014). Historical, observed, and modeled wildfire severity in montane forests of the Colorado Front Range. PLoS ONE 9:e106971. doi: 10.1371/journal.pone.0106971

Shipek, F. (1993). "Kumeyaay plant husbandry: fire, water, and erosion control systems," in Before the Wilderness. Environmental Management by Native Californians, eds T. C. Blackburn and K. Anderson (Menlo Park, CA: Ballena Press), 379-388.

Shive, K. L., Sieg, C. H., and Fulé, P. Z. (2013). Pre-wildfire management treatments interact with fire severity to have lasting effects on post-wildfire vegetation response. For. Ecol. Manag 297, 75-83. doi: 10.1016/j.foreco.2013.02.021

Skinner, C. N., Burk, J. H., Barbour, M. G., Franco-Vizcaíno, E., and Stephens, S. L. (2008). Influences of climate on fire regimes in montane forest of north-western Mexico. J. Biogeogr. 35, 1436-1451. doi: 10.1111/j.1365-2699.2008.01893.x

Skinner, C. N., and Taylor, A. H. (2018). "Southern Cascades bioregion," in Fire in California's Ecosystems (Berkeley, CA: University of California Press), 195-218. doi: 10.1525/9780520961913-015

Skinner, C. N., Taylor, A. H., Agee, J. K., Briles, C. E., and Whitlock, C. L. (2018). "Klamath mountains bioregion," in Fire in California's Ecosystems (Berkeley, CA: University of California Press), 171-194. doi: 10.1525/9780520961913-014

Smith, H. G., Sheridan, G. J., Lane, P. N. J., Nyman, P., and Haydon, S. (2011). Wildfire effects on water quality in forest catchments: a review with implications for water supply. J. Hydrol. 396, 170-192. doi: 10.1016/j.jhydrol.2010.10.043

Spies, T. A., Hammer, R., White, E. M., Kline, J. D., Bailey, J., Bolte, J., et al. (2014). Examining fire-prone forest landscapes as coupled human and natural systems. Ecol. Soc. 19:9. doi: 10.5751/ES-06584-190309

Spies, T. A., Stine, P. A., Gravenmier, R., Long, J. W., and Reilly, M. J. (2018a). Synthesis of Science to Inform Land Management Within the Northwest Forest Plan Area. General Technical Report, Volume 3, PNW-GTR-966. Portland, OR: U.S. Department of Agriculture, Forest Service, Pacific Northwest Research Station.

Spies, T. A., Stine, P. A., Gravenmier, R. A., Long, J. W., and Reilly, M. J. (2018b). Volume 3-Synthesis of Science to Inform Land Management Within the Northwest Forest Plan Area. General Technical Report PNW-GTR-966:6251020. Portland, OR: USDA-FS, Pacific Northwest Research Station.

Sprugel, D. G. (1991). Disturbance, equilibrium, and environmental variability: What is 'natural' vegetation in a changing environment? Biol. Cons. 58, 1-18. doi: 10.1016/0006-3207(91)90041-7

Stephens, S. L., Collins, B. M., Biber, E., and Fulé, P. Z. (2016). US federal fire and forest policy: emphasizing resilience in dry forests. Ecosphere 7:ecs2.1584. doi: $10.1002 /$ ecs 2.1584

Stephens, S. L., Collins, B. M., Fettig, C. J., Finney, M. A., Hoffman, C. M., Knapp, E. E., et al. (2018). Drought, tree mortality, and wildfire in forests adapted to frequent fire. BioScience 68, 77-88. doi: 10.1093/biosci/bix146

Stephens, S. L., and Fulé, P. Z. (2005). Western pine forests with continuing frequent fire regimes: possible reference sites for management. J. For. 103, 357-362. doi: 10.1093/jof/103.7.357 
Stephens, S. L., and Gill, S. J. (2005). Forest structure and mortality in an oldgrowth Jeffrey pine-mixed-conifer forest in northwestern Mexico. For. Ecol. Mgt. 205, 15-28. doi: 10.1016/j.foreco.2004.10.003

Stephens, S. L., Skinner, C. N., and Gill, S. J. (2003). Dendrochronology-based fire history of a Jeffrey pine-mixed-conifer forest in the Sierra San Pedro Mártir, Mexico. Can. J. For. Res. 33, 1090-1101. doi: 10.1139/x03-031

Stephenson, N. L. (1998). Actual evapotranspiration and deficit: biologically meaningful correlates of vegetation distribution across spatial scales. J. Biogeogr. 25, 855-870. doi: 10.1046/j.1365-2699.1998.00233.x

Stevens, J. T., Collins, B. M., Miller, J. D., North, M. P., and Stephens, S. L. (2017). Changing spatial patterns of stand-replacing fire in California mixed-conifer forests. For. Ecol. Mgt. 406, 28-36. doi: 10.1016/j.foreco.2017.08.051

Stevens-Rumann, C. S., Kemp, K. B., Higuera, P. E., Harvey, B. J., Rother, M. T., Donato, D. C., et al. (2018). Evidence for declining forest resilience to wildfires under climate change. Ecol. Lett. 21, 243-252. doi: 10.1111/ele.12889

Stockdale, C. A., Bozzini, C., Macdonald, S. E., and Higgs, E. (2015). Extracting ecological information from oblique angle terrestrial landscape photographs: performance evaluation of the WSL Monoplotting Tool. Appl. Geogr. 63, 315-325. doi: 10.1016/j.apgeog.2015.07.012

Swetnam, T. W., Allen, C. D., and Betancourt, J. L. (1999). Applied historical ecology: using the past to manage for the future. Ecol. Appl. 9, 1189-1206. doi: 10.1890/1051-0761(1999)009[1189:AHEUTP]2.0.CO;2

Swetnam, T. W., and Baisan, C. H. (2003). "Tree-ring reconstructions of fire and climate history in the Sierra Nevada and Southwestern United States," in Fire and Climatic Change in Temperate Ecosystems of the Western Americas, eds T. T. Veblen, W. L. Baker, G. Montenegro, and T. W. Swetnam (New York, NY: Springer), 158-195. doi: 10.1007/0-387-21710-X_6

Swetnam, T. W., and Betancourt, J. L. (1998). Mesoscale disturbance and ecological response to decadal climatic variability in the American Southwest. J. Clim. 11, 3128-3147. doi: 10.1175/1520-0442(1998)011<3128:MDAERT>2.0.CO;2

Swetnam, T. W., Farella, J., Roos, C. I., Liebmann, M. J., Falk, D. A., and Allen, C. D. (2016). Multiscale perspectives of fire, climate and humans in western North America and the Jemez Mountains, USA. Phil. Trans. R. Soc. B 371:20150168. doi: 10.1098/rstb.2015.0168

Syphard, A. D., Keeley, J. E., Pfaff, A. H., and Ferschweiler, K. (2017). Human presence diminishes the importance of climate in driving fire activity across the United States. Proc. Natl. Acad. Sci. U.S.A. 114, 13750-13755. doi: 10.1073/pnas.1713885114

Taylor, A. H., and Skinner, C. N. (2003). Spatial patterns and controls on historical fire regimes and forest structure in the Klamath Mountains. Ecol. Appl. 13, 704-719. doi: 10.1890/1051-0761(2003)013[0704:SPACOH]2.0.CO;2

Taylor, A. H., Trouet, V., and Skinner, C. N. (2008). Climatic influences on fire regimes in montane forests of the southern Cascades, California, USA. Int. J. Wildl. Fire 17, 60-71. doi: 10.1071/WF07033

Taylor, A. H., Trouet, V., Skinner, C. N., and Stephens, S. (2016). Socioecological transitions trigger fire regime shifts and modulate fire-climate interactions in the Sierra Nevada, USA, 1600-2015 CE. Proc. Natl. Acad. Sci. U.S.A. 113, 13684-13689. doi: 10.1073/pnas.1609775113

Tepley, A. J., Swanson, F. J., and Spies, T. A. (2013). Fire-mediated pathways of stand development in Douglas-fir/western hemlock forests of the Pacific Northwest, USA. Ecology 94, 1729-1743. doi: 10.1890/12-1506.1

Tepley, A. J., Thomann, E., Veblen, T. T., Perry, G. L., Holz, A., Paritsis, J., et al. (2018). Influences of fire-vegetation feedbacks and post-fire recovery rates on forest landscape vulnerability to altered fire regimes. J. Ecol. 106, 1925-1940. doi: $10.1111 / 1365-2745.12950$

Tepley, A. J., Thompson, J. R., Epstein, H. E., and Anderson-Teixeira, K. J. (2017). Vulnerability to forest loss through altered postfire recovery dynamics in a warming climate in the Klamath Mountains. Glob. Change Biol. 23, 4117-4132. doi: $10.1111 /$ gcb.13704
Tepley, A. J., and Veblen, T. T. (2015). Spatiotemporal fire dynamics in mixedconifer and aspen forests in the San Juan Mountains of southwestern Colorado, USA. Ecol. Monog. 85, 583-603. doi: 10.1890/14-1496.1

van Wagtendonk, J. W., and Fites-Kaufman, J. (2006). "Sierra Nevada bioregion," in Fire in California's Ecosystems, eds N. G. Sugihara, J. W. van Wagtendonk, K. E. Shaffer, J. Fites-Kaufman, and A. E. Thode (Berkeley, CA: University of California Press), 264-294.

Voelker, S. L., Merschel, A. G., Meinzer, F. C., Ulrich, D. E. M., Spies, T. A., and Still, C. J. (2019). Fire deficits have increased drought sensitivity in dry conifer forests: fire frequency and tree-ring carbon isotope evidence from Central Oregon. Glob. Change Biol. 25, 1247-1262. doi: 10.1111/gcb. 14543

WA DNR. (2017). Twenty Year Forest Health Strategic Plan for Eastern Washington, Olympia, WA: WA DNR.

Wahl, E. R., Zorita, E., Trouet, V., and Taylor, A. H. (2019). Jet stream dynamics, hydroclimate, and fire in California from $1600 \mathrm{CE}$ to present. Proc. Natl. Acad. Sci. U.S.A. 116, 5393-5398. doi: 10.1073/pnas.1815292116

Walker, B., Holling, C. S., Carpenter, S. R., and Kinzig, A. P. (2004). Resilience, adaptability and transformability in social-ecological systems. Ecol. Soc. 9:5. doi: 10.5751/ES-00650-090205

Westerling, A. L. (2016). Increasing western US forest wildfire activity: sensitivity to changes in the timing of spring. Phil. Trans. R. Soc. B 371:20150178. doi: $10.1098 /$ rstb. 2015.0178

White, R. (2015). It's Your Misfortune and None of My Own: A New History of the American West. Norman, OK: University of Oklahoma Press.

Williams, A. P., Allen, C. D., Macalady, A. K., Griffin, D., Woodhouse, C. A., Meko, D. M., et al. (2013). Temperature as a potent driver of regional forest drought stress and tree mortality. Nat. Clim. Chang. 3, 292-297. doi: $10.1038 /$ nclimate 1693

Williams, J. W., and Jackson, S. T. (2007). Novel climates, no-analogue communities, and ecological surprises. Front. Ecol. Env. 5, 475-482. doi: $10.1890 / 070037$

Wu, J., and Loucks, O. L. (1995). From balance of nature to hierarchical patch dynamics: a paradigm shift in ecology. Quart. Rev. Biol. 70, 439-466. doi: $10.1086 / 419172$

Young, D. J. N., Stevens, J. T., Earles, J. M., Moore, J., Ellis, A., Jirka, A. L., et al. (2017). Long-term climate and competition explain forest mortality patterns under extreme drought. Ecol. Lett. 20, 78-86. doi: 10.1111/ele.12711

Conflict of Interest Statement: RG is self-employed by the company RW Gray Ltd.

The remaining authors declare that the research was conducted in the absence of any commercial or financial relationships that could be construed as a potential conflict of interest.

The handling editor declared a shared affiliation, though no collaboration, with two of the authors, $\mathrm{CC}$ and $\mathrm{MB}$, at the time of review.

Copyright (c) 2019 Hessburg, Miller, Parks, Povak, Taylor, Higuera, Prichard, North, Collins, Hurteau, Larson, Allen, Stephens, Rivera-Huerta, Stevens-Rumann, Daniels, Gedalof, Gray, Kane, Churchill, Hagmann, Spies, Cansler, Belote, Veblen, Battaglia, Hoffman, Skinner, Safford and Salter. This is an open-access article distributed under the terms of the Creative Commons Attribution License (CC BY). The use, distribution or reproduction in other forums is permitted, provided the original author(s) and the copyright owner(s) are credited and that the original publication in this journal is cited, in accordance with accepted academic practice. No use, distribution or reproduction is permitted which does not comply with these terms. 